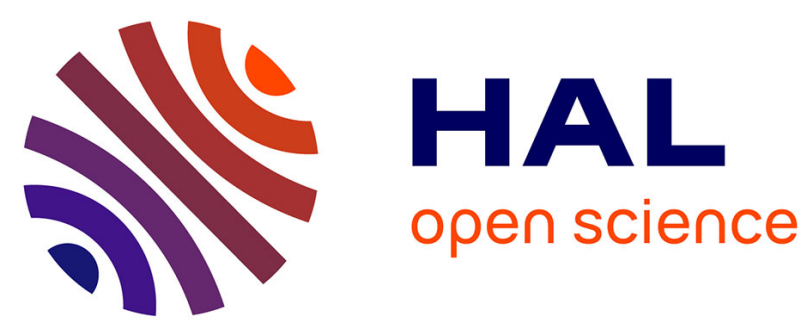

\title{
Sediment dispersal from a typical Mediterranean flood: The Têt River, Gulf of Lions
}

François Bourrin, Patrick L Friend, Carl L Amos, Eleonora Manca, Caroline Ulses, Albert Palanques, Xavier Durrieu de Madron, C.E.L. Thompson

\section{To cite this version:}

François Bourrin, Patrick L Friend, Carl L Amos, Eleonora Manca, Caroline Ulses, et al.. Sediment dispersal from a typical Mediterranean flood: The Têt River, Gulf of Lions. Continental Shelf Research, 2008, 28 (15), pp.1895-1910. 10.1016/j.csr.2008.06.005 . hal-00519751

\section{HAL Id: hal-00519751 \\ https://hal.science/hal-00519751}

Submitted on 16 Sep 2021

HAL is a multi-disciplinary open access archive for the deposit and dissemination of scientific research documents, whether they are published or not. The documents may come from teaching and research institutions in France or abroad, or from public or private research centers.
L'archive ouverte pluridisciplinaire HAL, est destinée au dépôt et à la diffusion de documents scientifiques de niveau recherche, publiés ou non, émanant des établissements d'enseignement et de recherche français ou étrangers, des laboratoires publics ou privés.

\section{(ㄷ)(1) $\$$}

Distributed under a Creative Commons Attribution - NonCommerciall 4.0 International 


\title{
Sediment dispersal from a typical Mediterranean flood: The Têt River, Gulf of Lions
}

\author{
F. Bourrin ${ }^{\mathrm{a}, \mathrm{b}, *}$, P.L. Friend ${ }^{\mathrm{c}, 1}$, C.L. Amos ${ }^{\mathrm{c}}$, E. Manca ${ }^{\mathrm{c}}$, C. Ulses $^{\mathrm{d}}$, A. Palanques ${ }^{\mathrm{e}}$, \\ X. Durrieu de Madron ${ }^{a}$, C.E.L. Thompson ${ }^{\mathrm{c}}$ \\ ${ }^{a}$ Centre de Formation et de Recherche sur l'Environnement Marin, Université de Perpignan, 52 Avenue de Villeneuve, 66860 Perpignan Cedex, France \\ b Observatoire Océanologique de Villefranche, Laboratoire d'Océanographie de Villefranche, UMR 7093, B.P. 08, 06238 Villefranche-sur-mer, France \\ ${ }^{c}$ School of Ocean and Earth Science, National Oceanography Centre Southampton, European Way, Southampton SO14 3ZH, UK \\ ${ }^{\mathrm{d}}$ Pole d'Oceanographie Côtiere de l'Observatoire Midi-Pyrenées-Laboratoire d'Aerologie, 14 Avenue Edouard Belin, 31400 Toulouse, France \\ e Institut de Ciències del Mar (CSIC), Passeig Marítim de la Barceloneta, 37-49 E-08003 Barcelona, Spain
}

This paper describes an integrated study of a typical Mediterranean flood event in the Gulf of Lions. A flood with a 5-year return interval occurred in the Têt River basin and adjacent inner-shelf in the Gulf of Lions, northwest Mediterranean, during April 2004. Data were collected during this flood as part of event-response investigations of the EU-funded Eurostrataform (European Margin Strata Formation) project. Southeasterly storm winds led to a flood which directly modified the inner-shelf hydrodynamics. Sediment delivery to the coastal zone during this flood represented more than half of the mean annual discharge of the Tet River to the Gulf of Lions. This river transported a large amount of sand in suspension, representing $25 \%$ of the total suspended load, and as bedload representing $8 \%$ of the total load, during this event. Sand introduced in the nearshore was transported northwards during the peak storm and nourished a small delta. Fine sediments were separated from coarse sediments at the river mouth, and were advected southwards and seawards by the counter-clockwise general circulation. Fine-grained sediments were transported via a hypopycnal plume along the coast towards the southern tip of the Gulf of Lions and the Cap Creus canyon. The along-shore currents, which intensified from north to south of the Gulf of Lions, particularly between the Cap Creus promontory and the Cap Creus canyon, favoured the transfer of fine-grained sediments from the continental shelf of the Gulf of Lions towards the continental slope. Our results show that floods with a few-year return interval in small coastal rivers can play a significant role in the transport of sediments on microtidal continental margins and their export from the shelf through canyons.

\section{Introduction}

River floods are important processes in the land-to-sea transfer of sediment and associated contaminants (e.g. metals and pathogens). River floods can be classified into two different types: seasonal floods and flash-floods. Seasonal floods are generally associated with large systems such as the Amazon and the Huanghe (Yellow River) rivers, and are characterised by seasonal increase in river discharge caused by prolonged snow melting or monsoon conditions. Occurring during several weeks or months, meteorological conditions that have caused these floods are not

\footnotetext{
* Corresponding author at: Observatoire Océanologique de Villefranche, Laboratoire d'Océanographie de Villefranche, UMR 7093, B.P. 08, 06238 Villefranche-surmer, France. Tel.: +33 493763717; fax: +33 493763739 .

E-mail address: fbourrin@obs-vlfr.fr (F. Bourrin).

${ }^{1}$ Present address: Maersk Oil, Esplanaden 50, 1263 Copenhagen K, Denmark.
}

directly linked with conditions at the coast. Seasonal floods can also affect smaller systems under prolonged storm/typhoon conditions (Liu and Lin, 2004). By contrast, flash-floods are short and intense events occurring during a few hours or days, and provoked under intense meteorological conditions. Flash-floods are common in the watersheds emptying into the Mediterranean Sea, and are associated with small mountainous catchments influenced by brief meteorological marine storm events during which depressions over the sea induce rapid and extreme rainfall over coastal relief. The result is a sudden river discharge of fresh water and sediment to the coastal zone. In this case, hydrology and water stratification in the inner-shelf are closely linked with local meteorological conditions. These floods affecting small coastal rivers under marine storm conditions are similar to the oceanic floods defined by Wheatcroft (2000).

Flash-floods occur over short time periods on small rivers, with the key aspect that the receiving basin is under the influence of 
the storm that led to flooding when the flood pulse reaches the sea (Wheatcroft, 2000). Due to the event-driven nature of the discharge in small rivers, most sediment reaching the sea from them usually does so during flash-floods. As the annual load per basin area of small rivers is greater than that of moderate to large size rivers, it is particularly important for global sediment flux studies to investigate flash-floods in which steep basin topography can give rise to a high potential sediment discharge (Milliman and Syvitski, 1992). Sediment delivered to the sea during such floods may be stored, at least temporarily in prodeltas or midshelf mud belts, or bypass these reaching the slope/canyon region and thence the abyssal plain. Globally, small rivers are estimated to account for around half the annual suspended sediment load to the sea (Milliman and Syvitski, 1992). Flash-floods, due to their short duration and small spatial scales, require novel sampling and modelling strategies (Wheatcroft, 2000).

Flash-floods have been investigated in various small mountainous systems. Some studies have focused on the dynamics and the fate of sudden river inputs to the coastal zone (Hill et al., 2000; Palinkas et al., 2005; Wheatcroft and Borgeld, 2000). Other studies have focused on the river system (runoff, fresh water and solid fluxes) during flash-floods (Gaume et al., 2004; Winston and Criss, 2002). Few studies have investigated both the processes in the river catchment and in the adjacent coastal zone. In this paper, we describe a 5-year river return interval, flood event on the Têt River and the associated fluxes of sediment and water across the continental shelf in the southwestern Gulf of Lions (northwest Mediterranean). The sediment dynamics and the main conditions leading to these fluxes are described including sediment fluxes on the shoreface/inner-shelf and across the prodelta, and the links between the shoreface/inner-shelf and canyon heads. The flood event lasted less than 1 day, from 16 to 17 of April 2004 with a peak hourly discharge of $683 \mathrm{~m}^{3} \mathrm{~s}^{-1}$. The flood described in this paper is similar to oceanic floods described by Wheatcroft (2000), but in our case the flood was generated under storm marine conditions rather than oceanic conditions. The short-term duration of the flood event, the semi-ephemeral character of the Têt River channel in summer time and the origin of this flood allow us to name this event as a storm-generated flood or flash-flood. The aim of the study is to quantify the contribution of floods with a relatively short return interval to land-sea sediment fluxes in the southwestern Gulf of Lions. A source-to-sink approach is followed through the investigation of: (1) rainfall intensity and watershed localisation; (2) coarse and fine-grained sediment transport by the river; (3) dispersal and deposition of both coarse and fine-grained sediment in the nearshore; and (4) dispersal of fine-grained sediment towards the shelf edge and the canyon heads.

\section{Regional settings}

\subsection{Freshwater inputs}

The Têt River discharges into the southwestern part of the Gulf of Lions (Fig. 1a). The Têt catchment $\left(1396 \mathrm{~km}^{2}\right)$ has a mean altitude of $1023 \mathrm{~m}$ and a mean slope of $12.4^{\circ}$ (Ludwig et al., 2004). Its maximum headwater elevation is at $2100 \mathrm{~m}$ and the river length is about $100 \mathrm{~km}$ (Garcia-Esteves et al., 2007). The Têt River basin can thus be considered to be a small mountainous river (Milliman and Syvitski, 1992). Precipitation for the entire basin range is $\sim 757 \mathrm{~mm} \mathrm{yr}^{-1}$ (average over the $1980-2000$ period); the rainfall pattern is characterised by long dry periods interrupted by short, violent marine events that can result, within a few hours, in flood events. The average liquid discharge at the gauging station at Perpignan, $10 \mathrm{~km}$ upstream of the mouth, is $10.82 \mathrm{~m}^{3} \mathrm{~s}^{-1}$.
Instantaneous discharge can reach $1800 \mathrm{~m}^{3} \mathrm{~s}^{-1}$ during major floods associated with extreme rainfall events (Serrat et al., 2001). Extreme floods (mean daily liquid discharge of up to $540 \mathrm{~m}^{3} \mathrm{~s}^{-1}$ ) have a 5-year return interval, whilst relatively smaller flood events (mean daily liquid discharge of $180 \mathrm{~m}^{3} \mathrm{~s}^{-1}$ ) have a return interval of 2 years. In order to reduce the intensity of peak floods, a retention dam was built in 1978 at Vinça, $\sim 50 \mathrm{~km}$ upstream of the mouth, on the border between the mountainous part and the alluvial plain of the Têt River catchment.

\subsection{Sediment input and prodelta deposits}

Flash-floods occur mainly during the autumn, at which time most of the total annual suspended load is transported to the Gulf of Lions: $78 \%$ of the total sediment flux in the Têt River between 1980 and 1999 occurred in only 50 days $(0.7 \%$ of the total time; from Serrat et al, 2001). The mean annual suspended sediment discharge from the Têt River, averaged over the 1978-2004 period, is $\sim 61( \pm 18) \times 10^{3} \mathrm{t}$ (Bourrin et al., 2006). The maximum suspended sediment concentration $\left(47 \mathrm{~g} \mathrm{~L}^{-1}\right)$ was recorded during a catastrophic flood event in the 1940s (Serrat et al., 2001). An ephemeral fluid mud deposit, composed of silts and clays, has often been observed on the inner-shelf in front of the Têt River mouth at a depth of $\sim 30 \mathrm{~m}$ after flood events (Buscail et al., 1990, 1995; Courp and Monaco, 1990; Guidi-Guilvard and Buscail, 1995). This thin deposit covers the uppermost part of the prodelta of the Têt River. The short residence time and/or the weak preservation of this deposit are mainly due to resuspension by waves and currents during high energetic events (Guillén et al., 2006).

\subsection{Coastal circulation and waves}

The coastal circulation in the western part of the Gulf of Lions is highly variable and dependant upon wind conditions. The main winds are the northwesterly "Tramontane" and the southeasterly "Marin". The Tramontane induces a cyclonic meso-scale circulation in the western part of the Gulf (Estournel et al., 2003). The coastal current induced by the prevailing northwesterly wind generally flows from north to south-southeast along the Roussillon coast (Millot, 1976). Circulation shifts are observed at the transition between northwesterly and southeasterly wind conditions. Southeasterly winds generate a counterclockwise circulation resulting in southward flow along the western coast of the GoL. These winds generally carry humid water masses over coastal relief, and in some cases cause extreme rainfall events. When southeasterly winds are well established, they induce alongshore currents flowing southward, intensified in the Cap Creus zone where the shelf narrows (Ulses et al., 2008a).

Waves are the main stirring mechanism causing bottom sediment resuspension in the western Mediterranean because tidal currents are negligible. In the study area, major storms are associated with waves coming from the east and southeast. Usually, large waves with significant wave height $(\mathrm{Hs})>6 \mathrm{~m}$ and period (Ts) $>12 \mathrm{~s}$ occur during autumn and winter. These are able to resuspend sediment on the inner and middle shelf (Ferré et al., 2005; Guillén et al., 2002; Palanques et al., 2002; Puig et al., 2001).

\subsection{Shelf sedimentation and export to canyons}

The Gulf of Lions margin is characterised by a sandy shoreline changing progressively to a silty inner-shelf to about $50 \mathrm{~m}$ water depth (Aloïsi et al., 1973). A shore-parallel mid-shelf mud-belt is located between 50 and $80 \mathrm{~m}$ water depths and its thickness reflects the predominance of sediment inputs from the Rhône 


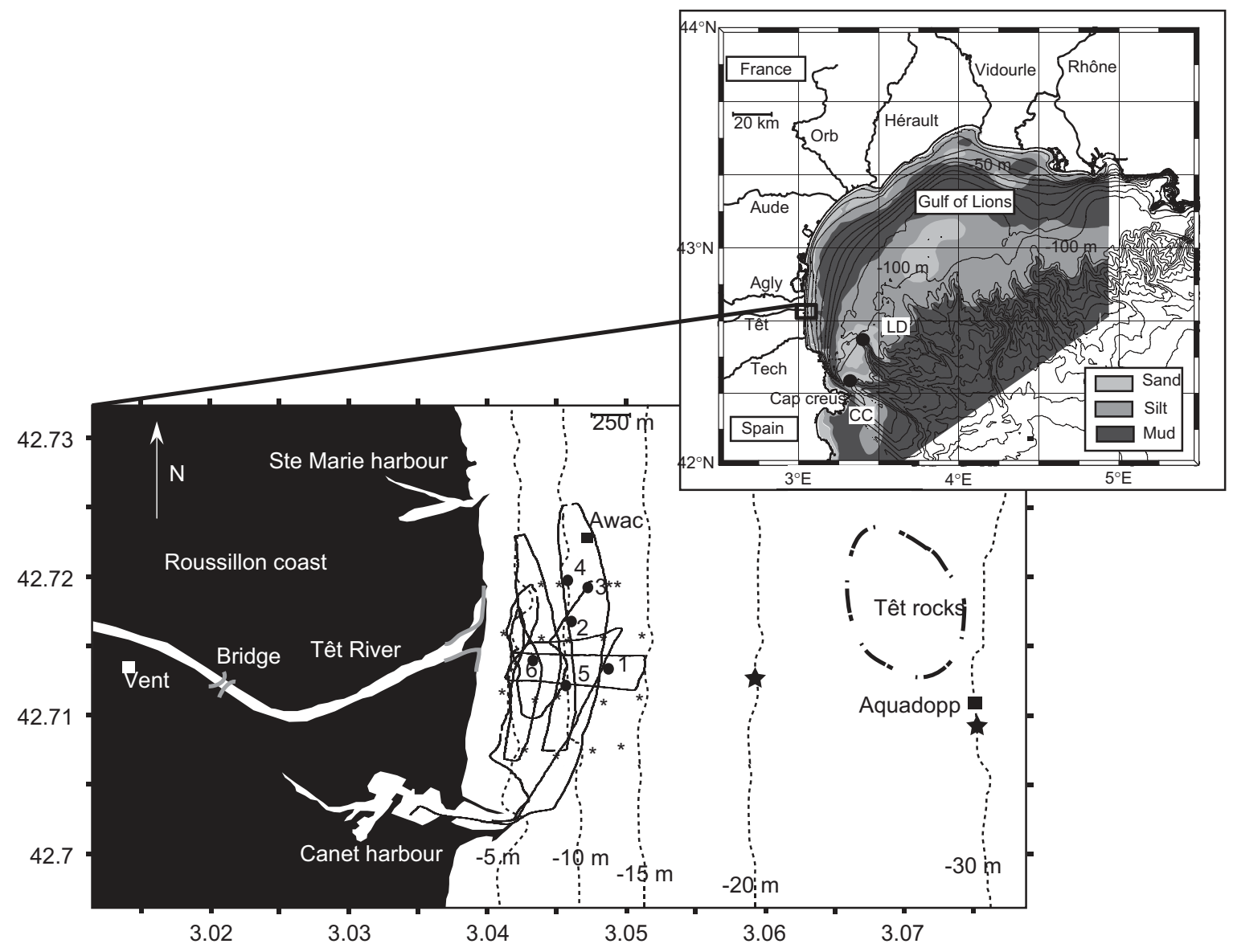

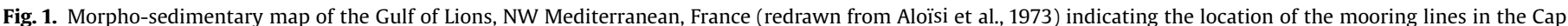

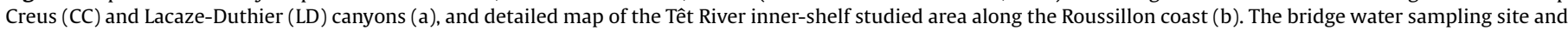

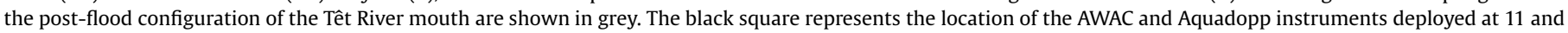

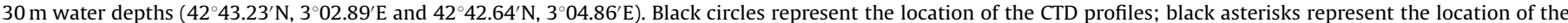


bathymetry and ADCP survey.

River over the coastal rivers of the western Gulf of Lions (Fig. 1a). During periods of generalised flooding of Gulf of Lions rivers, finegrained dispersal of sediment by hypopycnal plumes is influenced by the general southwestward along-shore circulation on the shelf, and preferential export occurs in the southwestern canyons (Palanques et al., 2006; Ulses et al., 2008a).

\section{Material and methods}

\subsection{Meteorological measurements}

The wind field was measured every 5 min with an ultrasonic wind sensor (Vaisala WAS425) installed on the roof of the waste station of Canet-en-Roussillon (Vent station, $42^{\circ} 42.82^{\prime} \mathrm{N}$ $03^{\circ} 00.70^{\prime} \mathrm{E}$ ), at $6 \mathrm{~m}$ above the ground (Fig. 1b), from 11 February to 16 August 2004. Statistical parameters of the wind field (mean and maximum hourly speed and direction) were extracted from high frequency measurements. Rainfall was measured daily at 49 meteorological stations by the French national meteorological society (Météo France), covering the watershed of the Têt River in April 2004. Mean rainfall over the catchment area was estimated from a biharmonic spline interpolation (Sandwell, 1987) of mean daily precipitation measured at the 49 meteorological stations over the entire surface basin area during the 16 April 2004 flood event (Fig. 2).

\subsection{River measurements}

\subsubsection{Liquid discharge and river flow}

Hourly water discharge of the Têt River was measured at the Perpignan gauging station (station Y0474040 in the national data bank, "Hydro"), $10 \mathrm{~km}$ upstream from the river mouth $\left(42^{\circ} 42.21^{\prime} \mathrm{N}, 02^{\circ} 53.58^{\prime} \mathrm{E}\right)$. Surface water samples were collected at 6-hourly intervals from 16 April $20: 00 \mathrm{~h}$ to 20 April 14:00 h with a bucket $(\sim 5 \mathrm{~L})$ from a bridge $\sim 2 \mathrm{~km}$ from the river mouth (see Fig. 1b). Surface water velocity was estimated at the same time by measuring the elapsed time of displacement of natural debris over a known distance. River surface height was measured simultaneously at the same bridge with a limnimetric scale (DDE Pyrénées Orientales).

\subsubsection{Total suspended solids}

Water samples were filtered using $2 \mu \mathrm{m}$ Whatman GF standard filter paper. The mass of sediment retained was determined after drying at $100^{\circ} \mathrm{C}$ for $12 \mathrm{~h}$ and gives the instantaneous total suspended solids (TSS) concentration. Sands and organic flocs $>63 \mu \mathrm{m}$ were separated from silts and clays by gentle wet-sieving through a $63 \mu \mathrm{m}$ sieve. The organic flocs fraction is mostly composed of organic debris and plants. This fraction was determined by weighing after incineration for $12 \mathrm{~h}$ at $450^{\circ} \mathrm{C}$. Each of the remaining fractions was analysed for settling velocity and 


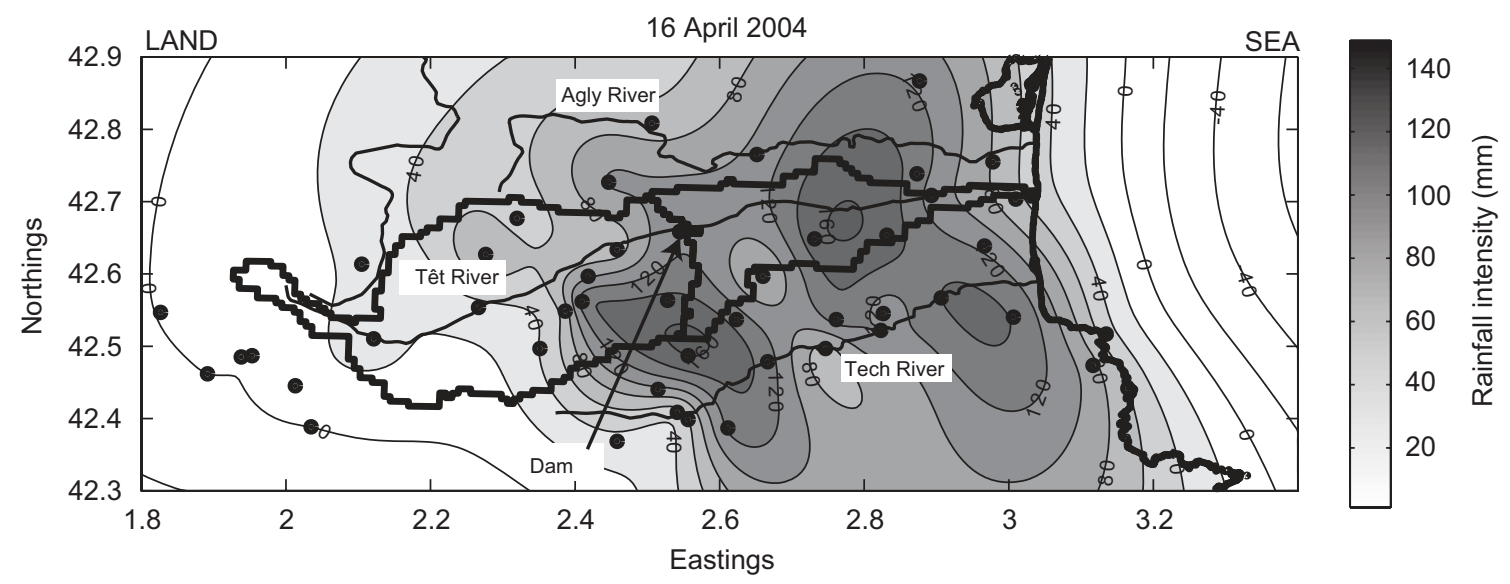



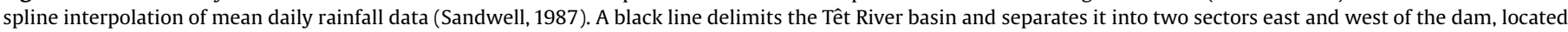
in the central part of the catchment area.

grain size using a settling column (sands) and a Coulter ${ }^{\mathrm{TM}}$ laser sizer (silts and clays).

\subsubsection{TSS discharge}

The fine-grained fraction was assumed to be fully mixed in the river water column in flooding conditions. The product of instantaneous suspended fine sediment concentration and instantaneous water discharge yields the instantaneous suspended fine sediment discharge. The total suspended fine sediment load of the event was obtained by interpolating between the measurements.

The Rouse equation, defining the vertical distribution of concentration $c$, in an open channel flow (Rouse, 1937) was used to estimate the suspended sand transport in the Têt River during the April 2004 flood event:

$\frac{c}{c_{\mathrm{a}}}=\left(\frac{h-y}{y} \times \frac{a}{h-a}\right)^{Z}$,

where $c_{\mathrm{a}}$ is the concentration of sediment at a reference level $y / h=a, h$ is the total water depth and $y$ is the height above the bed; $Z=w_{s} /\left(\kappa \times u^{*}\right)$ is the Rouse number, $w_{\mathrm{s}}$ is the measured particle settling velocity, $\kappa=0.4$ is the von Karman constant. The shear velocity, $u_{*}$, is estimated from a log-law velocity profile originating from surface measurements, and following the equation:

$u_{*}=\frac{\kappa \times u(z)}{\log \left(z / z_{0}\right)}$,

where $u(z)$ is the reference velocity at a height $z=h$ (flow depth or river surface), $z_{0}=0.033 \mathrm{Ks}=10 \mathrm{~cm}$, where $\mathrm{Ks} \sim 3 \mathrm{~m}$ is the size of the boulders in the riverbed. Depth-integrated concentrations of sand during this event were derived from Rouse profiles, and the product of this and the instantaneous river discharge yields the instantaneous suspended load of sand. The total suspended sand discharge of the event was obtained by interpolating between the measurements. The estimation of river suspended sand fluxes is dependant on the measurement of surface flow speed, flow depth and concentration of sand at river surface. Some error has been introduced in the estimated flux from the method used and we have to be very careful with the final estimation. The total suspended load during the April flood event in the Têt River was obtained by adding the suspended fine sediment and suspended sand discharge.

\subsubsection{Bedload discharge}

The SEDTRANS model version 0.94 upgrading the previous version of the model ( $\mathrm{Li}$ and Amos, 1995, 2001) was used to estimate the sand bedload transport at the gauging station during this event. The inputs of the model are depth, flow velocity, and the mean grain size of particles at the bed surface at the gauging station. The calculation method for the sand bedload transport estimation was established from the transport equation of Yalin (1963).

\subsection{Nearshore measurements}

\subsubsection{Seabed}

Twenty seabed samples were collected by Van Veen grab on 18 April 2004 from the top and front of the prodelta (5-15 m depth), and 18 swash zone samples were collected from the beaches to the north and south of the river mouth (Fig. 1b). Sand and silt fractions were separated by gentle wet-sieving using a $63 \mu \mathrm{m}$ sieve, and then analysed for settling velocity and grain size using a settling column and a Coulter ${ }^{\mathrm{TM}}$ laser sizer.

Grain size trend analysis following the procedure of Gao and Collins (1992) was applied to the delta top and front samples. This method is based on the assumption that spatial changes in surface sediment can yield the residual transport paths. First, the grainsize analyses of the 20 seabed samples were derived to obtain for each sample the mean grain-size $(\mu)$, sorting $(\sigma)$ and skewness (Sk) (using the method by Folk and Ward, 1957) and the statistical moments M1, M2 and M3 (calculated by means of the equations issued from the moment theory by Rivière (1977)). Two cases are generally representative of sediment transport: $\mu_{2}>\mu_{1}, \sigma_{2}<\sigma_{1}$, $\mathrm{Sk}_{2}<\mathrm{Sk}_{1}$ (case 1: sediment becomes finer, better sorted and more negatively skewed) or $\mu_{2}<\mu_{1}, \sigma_{2}<\sigma_{1}, \mathrm{Sk}_{2}>\mathrm{Sk}_{1}$ (case 2: sediment becomes coarser, better sorted and more positively skewed). The Grain Size Trend Analysis FORTRAN program (Gao, 1996) was used to calculate the trend vectors comparing the moments between neighbouring pairs of sampling sites within the critical distance (defined from the sampling grid, $200 \mathrm{~m}$ in our study) and considering the coordinates of each sampling site and the scaling factor A (ratio between the distance of $1^{\circ}$ of latitude and the distance of $1^{\circ}$ of longitude). Trend vectors were interpolated in a regular grid of 60 points (using the Kriging method) and plotted using SURFER ${ }^{\odot}$ software (Golden Software Inc.).

A $200 \mathrm{kHz}$ single beam Lowrance echo-sounder survey (Fig. 1b) was conducted on the inner-shelf at 3-10 m water depths in the river mouth area on 18 April 2004 06:30-09:00 h and used to derive a detailed bathymetric map of the coastal zone. Two sediment cores were also collected by SCUBA divers using transparent Perspex tubes $(20 \mathrm{~cm}$ length, $4 \mathrm{~cm}$ diameter) at 20 
and $30 \mathrm{~m}$ water depths on 28 April 2004 (Fig. 1b). Sediment cores were sliced every centimetre. Grain-size analyses were performed on samples, sonicated for $5 \mathrm{~min}$ in Milli Q-filtered water, using a Malvern Mastersizer 2000 particle size analyser equipped with a sample dispersion unit.

\subsubsection{Water column}

A $600 \mathrm{kHz}$ hull-mounted (RDI) ADCP survey (Fig. 1b) was conducted on the inner-shelf at 3-10 $\mathrm{m}$ water depths in front of the river mouth on 18 April 2004, 06:30-09:00 h, at the same time as the bathymetric survey, in order to monitor the instantaneous spatial structure of the river plume. Vertical profiles of temperature, conductivity, turbidity and fluorescence were made using an autonomous multiparametric YSI 6600 EDS probe $(1 \mathrm{~Hz}$ sampling rate) during the ADCP survey (Fig. 1b). Data were corrected for pressure reversal and averaged in 0.5 dbar bins. Salinity was derived from conductivity and temperature probe measurements according to algorithms found in Standard Methods for the Examination of Water and Wastewater (1989). Turbidity, acquired initially in NTU, was converted to TSS concentration, using gravimetric measurements of water samples collected at the surface of the river plume. The relationship between optical measurements and TSS concentrations was the following: MES $\left(\mathrm{mg} \mathrm{L}^{-1}\right)=1.5929 \mathrm{NTU}+5.4768\left(r^{2}=0.71\right)$. Optical measurements are sensitive to particle size distribution and concentration.

In situ grain-size measurements were performed simultaneously with a Sequoia LISST-100 type B (1.25-250 $\mu \mathrm{m}$ range). An upward-looking Acoustic Doppler Profiler (ADP) AWAC (Nortek) equipped with a wave gauge was deployed near the survey area (see Fig. $1 \mathrm{~b})$ at $11 \mathrm{~m}$ water depth $\left(42^{\circ} 43.23^{\prime} \mathrm{N}, 3^{\circ} 02.89^{\prime} \mathrm{E}\right)$. Wave and current parameters were logged for $5 \mathrm{~min}$ every $30 \mathrm{~min}$. A downward looking Aquadopp Profiler $600 \mathrm{kHz}$ (Nortek) was installed on a buoy moored at $30 \mathrm{~m}$ water depth, $1.5 \mathrm{~nm}$ from the river mouth $\left(42^{\circ} 42.59^{\prime} \mathrm{N}, 03^{\circ} 04.78^{\prime} \mathrm{E}\right)$ to measure water column currents every 5 min.

The Sediview program (Land and Bray, 2000) was used to derive TSS concentrations from the average backscatter signal measured during the coastal vessel-mounted RDI ADCP survey, using an iterative method to solve a simplified version of the sonar equation (Urick, 1975):

$\log _{10} \mathrm{Mr}=S\left[\mathrm{Ks}+\mathrm{dB}+2 r\left(\alpha_{\mathrm{w}}+\alpha_{\mathrm{s}}\right)\right]$,

where $\mathrm{Mr}$ is the mass concentration per unit volume at range $r, S$ is the relative backscatter coefficient, Ks is the site and instrument dependant factor, $\mathrm{dB}$ is the measured relative backscatter intensity corrected for spherical spreading, $\alpha_{w}$ is the water attenuation coefficient computed using observed temperature and salinity near the transducer, and $\alpha_{s}$ is the sediment attenuation coefficient estimated from the measured depthaveraged median grain size of the suspended particles from the LISST instrument. Acoustically derived turbidity is dependent on grain size distribution and concentration, as well as particle shape and density. The calibration constants $S$ and Ks are determined by fitting the ADCP measured backscatter intensities with the optical turbidity measurements of the YSI multiparameter probe at the same time. Optical turbidity measurements are more sensitive to small particles and acoustic turbidity measurements are more sensitive to large particles (Creed et al., 2001). Calibrating acoustical measurements from optical measurements could lead to large errors in the estimation of TSS. In our study, the efficiency of the calibration between acoustically- and optically-derived TSS was relatively good $\left(r^{2}=0.98, n=83\right)$ with fitted coefficients Ks $=41.5$ and $S=33$. The low TSS concentration and unimodal grain-size repartition of TSS in coastal waters in front of the river mouth could be one reason for the low error on our estimation.

\subsection{Shelf and canyon head measurements}

The first satellite picture available after the passage of the lowpressure system over the study area was taken on 26 April 2004 from the MERIS sensor of ENVISAT satellite. The spectral band of total suspended concentration was extracted from the satellite data using Beam-VISAT software and algorithms. The particulate backscatter at $442 \mathrm{~nm}$ is deduced from the water-leaving reflectance spectrum and converted from optical units (backscatter in $\mathrm{m}^{-1}$ ) to geophysical units (concentration in $\mathrm{g} \mathrm{m}^{-3}$ ) using a fixed conversion factor (ESA, 2002) derived for measurements on water samples using a GF/F filter. The corresponding picture was used to observe the dispersal of turbid river plumes in the southwestern Gulf of Lions after the flood event.

Shelf-slope suspended sediment transport was monitored by deploying an Aanderaa RCM11 current meter equipped with a turbidimeter (OBS) on two moorings, $4 \mathrm{~m}$ above bottom, at $300 \mathrm{~m}$ water depth in the head of the Cap de Creus (CC) and LacazeDuthiers (LD) submarine canyons at the southern end of the Gulf, in April 2004 (Palanques et al., 2006; Fig. 1a). The sampling interval of the current meter was $20 \mathrm{~min}$. Data analysis and turbidity signal conversion procedures were described in Palanques et al. (2006).

\section{Results}

\subsection{Meteorological and oceanic conditions}

In April 2004, a depression over the NW Mediterranean (Fig. 3a) associated with southeasterly winds (Fig. 3b) and high rainfall induced a major flood event in the Têt River (5-year return interval) with a maximum hourly liquid discharge of $683 \mathrm{~m}^{3} \mathrm{~s}^{-1}$ on 16 April at 23:00 h (Fig. 3c). Mean precipitation over the total catchment area was evaluated to be $80 \mathrm{~mm}$ and locally exceeded $160 \mathrm{~mm}$, corresponding to $1 / 10$ of the total annual precipitation. Precipitation was concentrated over the lower part of the basin area (Fig. 2). The depression generated waves in the coastal zone of up to $\mathrm{Hs}=5 \mathrm{~m}$ and $\mathrm{Ts}=9 \mathrm{~s}$ (2-year return interval, Fig. 3d). Such waves are capable of resuspending bottom sediments to a depth of around $30 \mathrm{~m}$ (Guillén et al., 2006).

\subsection{River sediment fluxes}

\subsubsection{TSS concentrations}

The maximum measured TSS concentration of the surface river water was $1.2 \mathrm{~g} \mathrm{~L}^{-1}$ on 17 April at 08:00 h, i.e. after the peak liquid discharge (Fig. 3c). The TSS concentration was certainly higher at the peak flood but was not measured. TSS concentrations decreased as the river flow and water level decreased (Figs. 3c and 4). Fig. 4 illustrates the temporal variation in concentration of clay and silts $(<63 \mu \mathrm{m})$, sands $(>63 \mu \mathrm{m})$ and organic flocs $(>63 \mu \mathrm{m})$ in the suspended particulate matter in surface river water as well as the surface current speed $\left(\mathrm{m} \mathrm{s}^{-1}\right)$ and water level $(\mathrm{m})$. The maximum concentration of clay and silts in suspension reached $1.08 \mathrm{~g} \mathrm{~L}^{-1}$, and decreased as the surface water speed and water level decreased. Sand in suspension at the river surface $\left(\sim 0.15 \mathrm{~g} \mathrm{~L}^{-1}\right)$ was found after the peak river discharge, reaching about $10 \%$ of the total load. Organic flocs were also present ( $5 \%$ after the river peak discharge, $\sim 0.02 \mathrm{~g} \mathrm{~L}^{-1}$ ). A maximum river surface flow speed of $1.93 \mathrm{~m} \mathrm{~s}^{-1}$ and a water level of $2.14 \mathrm{~m}$ were measured the 17 April 2004 at 8:00 h after the flood peak. At the end of the flood, flow speed and water level decreased to $1.04 \mathrm{~m} \mathrm{~s}^{-1}$ and $0.6 \mathrm{~m}$, respectively. 


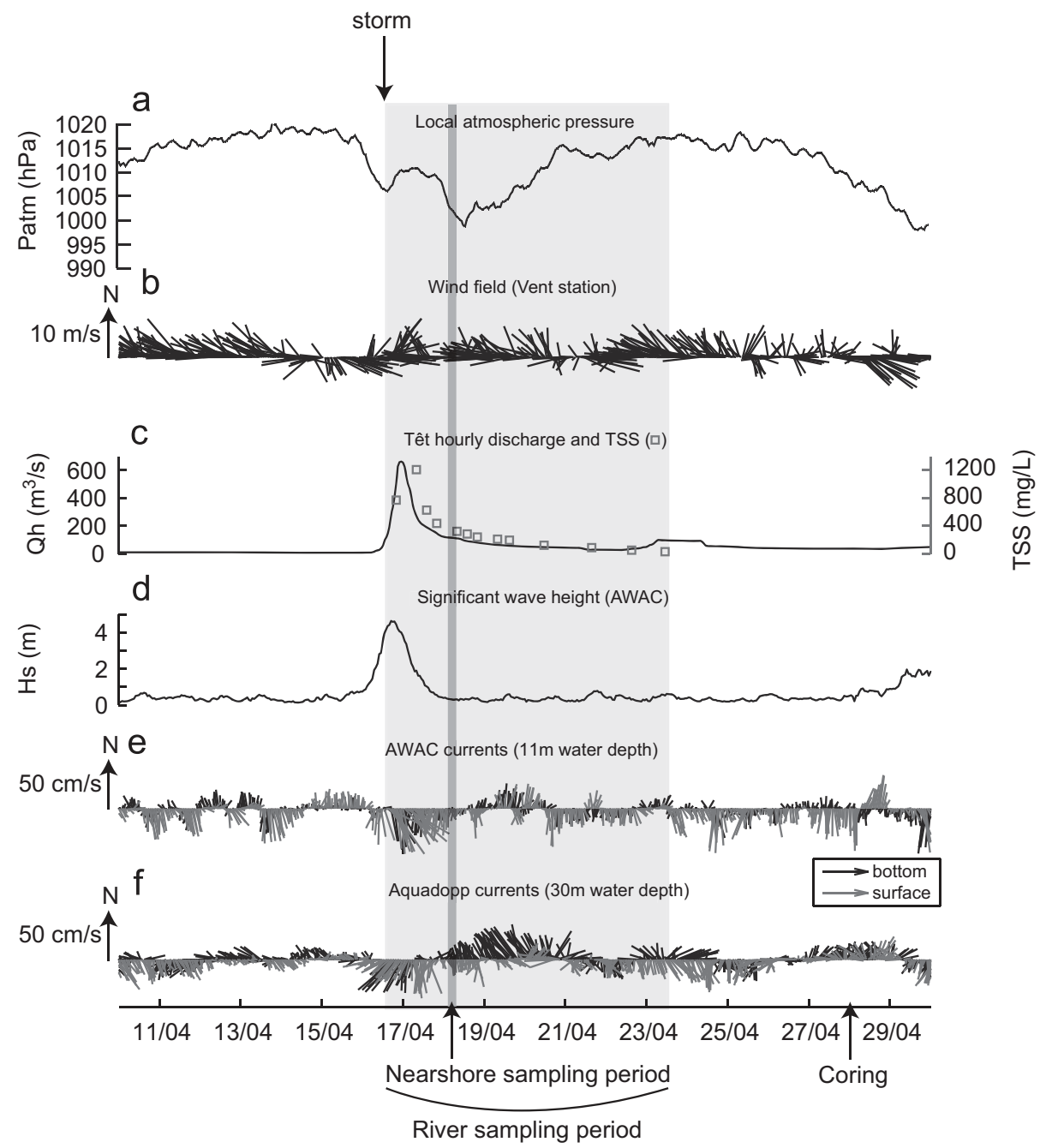

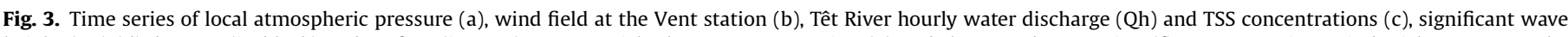

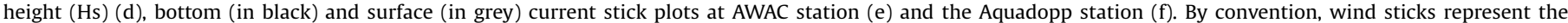

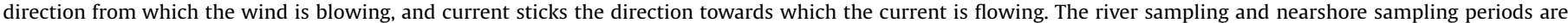
indicated by the shaded areas.

\subsubsection{TSS and bedload transport}

The total fine-grained suspended solid load reaching the sea during this flood was estimated to be $\sim 33.9 \pm 0.6 \times 10^{3}$ t. Rating curves developed from long-term measurements of TSS concentrations and instantaneous river discharge give a slightly higher value of $35.5 \times 10^{3} \pm 8.8 \times 10^{3} \mathrm{t}$ (Bourrin et al., 2006). The uncertainty on the estimation of fine-grained sediment fluxes is in this case about $25 \%$ and is more realistic than the uncertainty that we estimated on the measured fluxes ( $\sim 2 \%)$. River suspended sand transport was estimated from surface measurements extrapolated to the bottom using Rouse profiles (Fig. 5) and instantaneous river discharge. By this method it was estimated that $\sim 11.4 \pm 0.2 \times 10^{3} \mathrm{t}$ of sand were discharged in suspension to the coastal zone, representing $\sim 25 \%$ of the total suspended load $\left(45.3 \pm 0.8 \times 10^{3} \mathrm{t}\right)$ during this flood.

SEDTRANS model predictions give a bedload sand discharge to the coastal area of $\sim 3.9 \pm 1.7 \times 10^{3} \mathrm{t}$, which represents $\sim 8 \%$ of the total solid discharge $\left(49.3 \pm 2.5 \times 10^{3} \mathrm{t}\right)$ during this flood event.

\subsection{Nearshore hydrology}

Current profiles measured at the AWAC site at $11 \mathrm{~m}$ water depth and at the Aquadopp site at $30 \mathrm{~m}$ water depth (Fig. 3e and f) show a similar directional pattern, but differ in intensity. Surface and bottom currents were usually oriented towards the south at both sites, except during short-term southeasterly wind events, when currents veered towards the north. Before the flood/storm event, currents associated with southeasterly winds were oriented towards the north (until 16 April 2004, 03:00 h). During the flood, currents were oriented towards the south and the wind blew from the north (until 19 April 2004, 05:00 h). Sedimentary material resuspended by near-bed orbital currents during the storm would thus be advected mainly towards the southeast by bottom currents.

After the event, currents once again were oriented towards the north. The surface current reached a maximum speed $\left(0.73 \mathrm{~m} \mathrm{~s}^{-1}\right.$ at the $11 \mathrm{~m}$ water depth, AWAC site; and $0.57 \mathrm{~m} \mathrm{~s}^{-1}$ at $30 \mathrm{~m}$ water depth, Aquadopp site) during the storm peak (16 April 2004, 18:00 $\mathrm{h}$ ) when the southerly winds were well established. Bottom currents also reached a maximum $\left(0.43 \mathrm{~m} \mathrm{~s}^{-1}\right.$ at the $11 \mathrm{~m}$ water depth, AWAC site; and $0.30 \mathrm{~m} \mathrm{~s}^{-1}$ at $30 \mathrm{~m}$ depth, Aquadopp site) during the peak of the storm. The maximum wave orbital velocity reached $1.9 \mathrm{~m} \mathrm{~s}^{-1}$ at $11 \mathrm{~m}$ water depth (corresponding to $\mathrm{Hs}=4.7 \mathrm{~m}, \mathrm{Tp}=11 \mathrm{~s}$, Fig. $3 \mathrm{~d}$ ) at the storm peak, and could therefore resuspend sands of at least medium grain-size $(160 \mu \mathrm{m})$ at the AWAC site. 





during the flash-flood event of April 2004. The water level is measured from the riverbed.

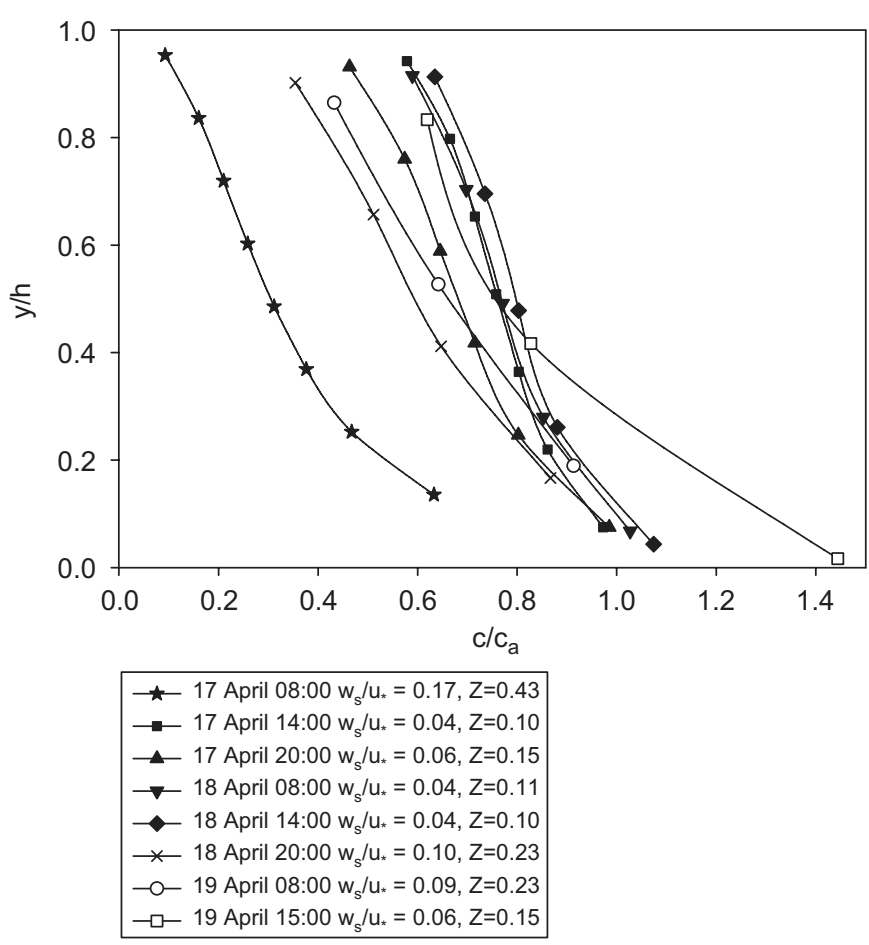

Fig. 5. Rouse profiles derived from river surface water samples and velocity measurements during the Têt oceanic flood of April 2004. $y$ is the depth above the bed, $h$ the total flow depth, $c$ the concentration at depth $y$ and $c_{a}$ the concentration at reference depth a above the bed $(a=y / h), w_{\mathrm{s}}$ the measured settling velocity of suspended particles, and $u^{*}$ is the shear velocity.

CTD profiles monitored at different locations in front of the river mouth (Fig. 1b) were used to characterise the structure of the water column during the sampling period (18 April 2004, 06:00-09:30 h). A 1-m-thick surface layer with low salinity ( $\sim 29-31$ ppt, Fig. $6 a)$, and relatively high temperature $\left(\sim 12.4^{\circ} \mathrm{C}\right.$, Fig. 6b) was identified at stations 1 and 5 south of the study area, in accordance with the position of the river plume pushed southwards by northerly winds. Below the surface layer, the water column appeared to be weakly stratified to the bottom.

\subsection{Fine-grained dispersal in the nearshore}

In the nearshore, at about $10 \mathrm{~m}$ water depth, high turbidity values ( $\sim 30 \mathrm{mg} \mathrm{L}^{-1}$, Fig. $\left.6 \mathrm{c}\right)$ and chlorophyll content $\left(\sim 12 \mu \mathrm{g} \mathrm{L}^{-1}\right.$, not shown) were measured with the CTD probe in the surface layer. In addition, a bottom nepheloid layer, less than $2 \mathrm{~m}$ thick, was observed with high TSS concentrations $\left(\sim 20 \mathrm{mg} \mathrm{L}^{-1}\right)$ and low chlorophyll values $\left(\sim 6 \mu \mathrm{g} \mathrm{L}^{-1}\right)$. In situ grain-size measurements with the LISST (Fig. 6d) show that the surface layer contained unimodal particles of $\sim 110 \mu \mathrm{m}$ diameter which are probably flocs. The bottom layer was composed of particles with a broad size range between 80 and $160 \mu \mathrm{m}$.

The ADCP survey took place during 18 April 2004 between 06:00 and 09:00 h, after the peak flood during a period of northwesterly winds and southward currents. Turbidity maps were derived from interpolation of TSS concentrations estimated from ADCP backscatter measurements (Fig. 7). At $\sim 2 \mathrm{~m}$ below the surface (Fig. 7a), the advection towards the southeast of the turbid river plume near the mouth can be seen. Maximum turbidity reached $\sim 40 \mathrm{mg} \mathrm{L}^{-1}$ at the river mouth and close to the harbour entrance. At mid-water column depth (Fig. 7b), no turbidity maximum was present, whereas at $\sim 2 \mathrm{~m}$ above the bottom (Fig. 7c), turbidity maxima were observed at the river mouth $\left(\sim 30 \mathrm{mg} \mathrm{L}^{-1}\right)$ and at the harbour entrance $\left(\sim 20 \mathrm{mg} \mathrm{L}^{-1}\right)$. Bottom turbidity remained relatively high in the entire area surveyed. Currents were oriented mainly towards the south at all depths during the survey, veering from the southeast at the surface to the south at the bottom. Current intensities decreased from $0.11 \mathrm{~m} \mathrm{~s}^{-1}$ at the surface to $0.06 \mathrm{~m} \mathrm{~s}^{-1}$ at the bottom during the survey (Fig. 7).

\subsection{Seabed imprint}

Sand size distributions for riverbed, beaches and nearshore were mainly unimodal. Delta and nearshore sands were of 


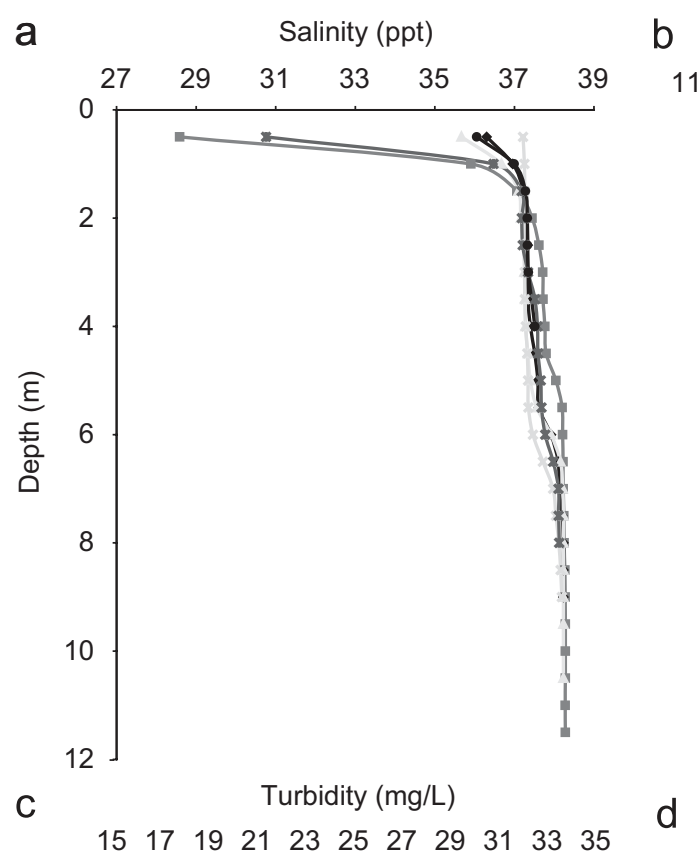

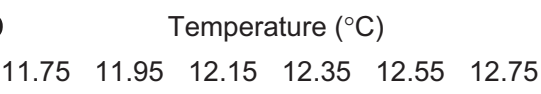
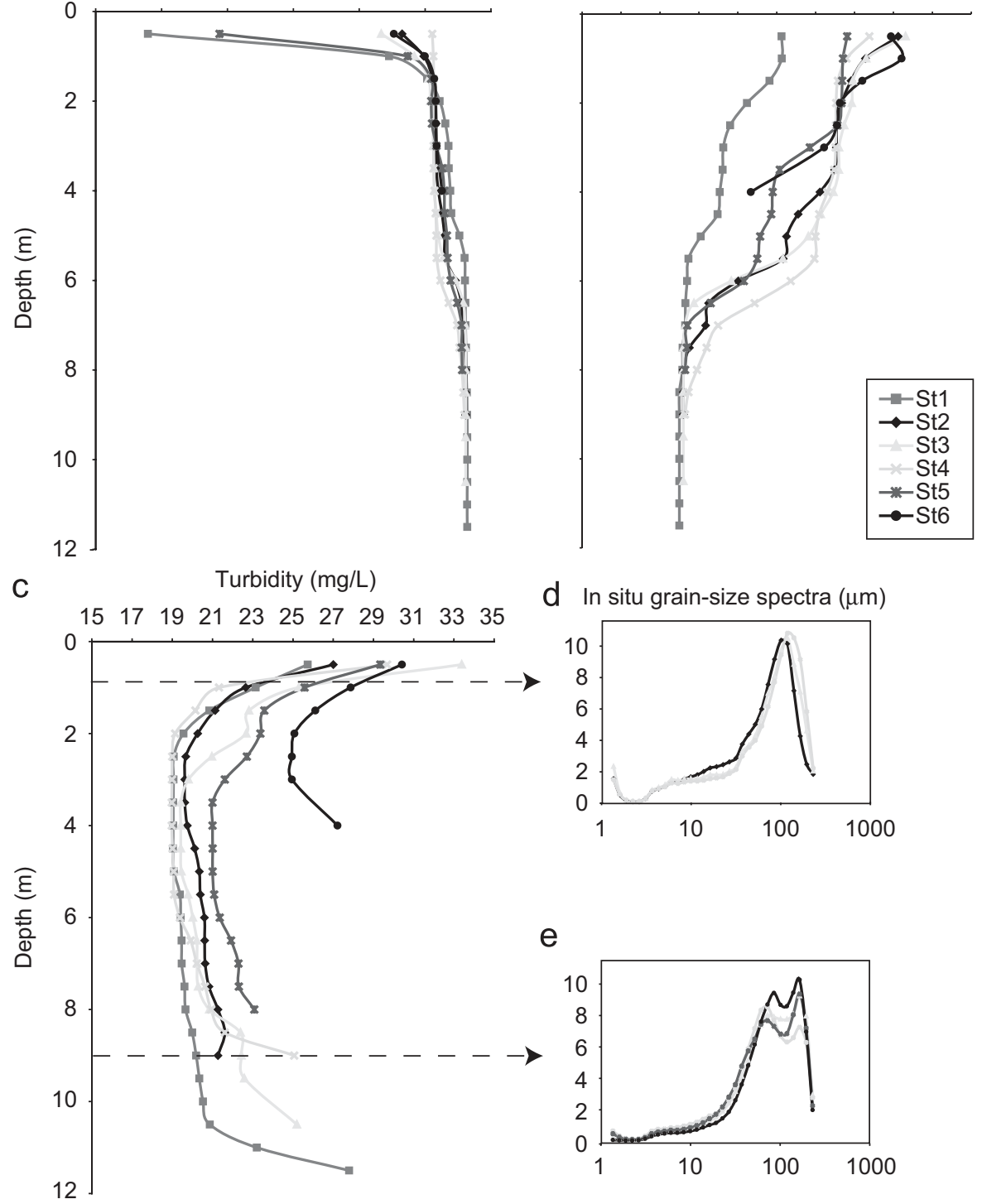

d In situ grain-size spectra $(\mu \mathrm{m})$

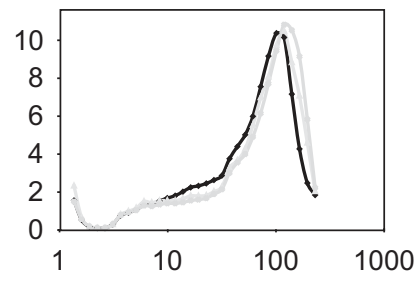

e

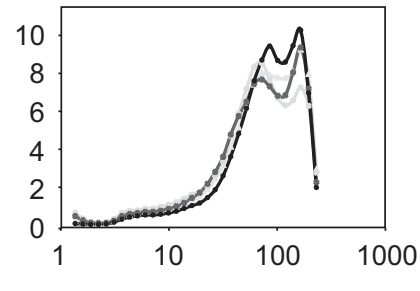

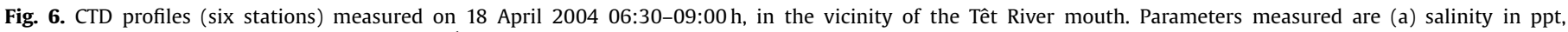
(b) temperature in ${ }^{\circ} \mathrm{C}$, and (c) turbidity in $\mathrm{mg} \mathrm{L}^{-1}$. In situ grain-size spectra measured with the LISST are indicated for the surface and bottom layers (d).

medium to very coarse grain size close to river mouth $\left(D_{50}=278 \mu \mathrm{m}\right.$ to $\left.1 \mathrm{~mm}\right)$; the riverbed sand had a variable mean grain size from fine to medium $\left(D_{50}=180-512 \mu \mathrm{m}\right)$. Sands from the north beach were coarser than those from the south. Sands were generally very well- to well-sorted, with sorting improving with distance from the mouth for both the northern and southern beaches. The Gao and Collins (1992) trend analysis indicated that net sand transport was generally in a northerly direction in the surf zone (Fig. 8). By contrast, the mud content of bottom sediment (3-10 $\mathrm{m}$ water depth) indicates that the settling of suspended matter from the surface plume was greatest south of the river mouth. Thus, there is a divergence in size population of sediment at the river mouth. Two additional sediment cores sampled at 20 and $30 \mathrm{~m}$ water depths show the presence of a superficial $(\sim 2 \mathrm{~cm})$ flood layer composed of fluffy material only at $20 \mathrm{~m}$ water depth.

\subsection{Canyon response to the event}

Bottom current intensity measured at the AWAC site $(11 \mathrm{~m}$ water depth), lagged current increase measured in the Cap Creus and Lacaze-Duthiers canyon by $\sim 6 \mathrm{~h}$, and reached intensities of $0.40 \mathrm{~m} \mathrm{~s}^{-1}$ for more than half a day (Fig. 9c). At the head of the Cap Creus canyon, about $50 \mathrm{~km}$ south, maximum bottom current magnitude reached about $0.80 \mathrm{~m} \mathrm{~s}^{-1}$, and current intensities $>0.60 \mathrm{~m} \mathrm{~s}^{-1}$ were measured for about $20 \mathrm{~h}$. Backscatter intensities measured by the ADP (AWAC) in the coastal zone are directly related to the quantity of suspended material in the water column. In the nearshore, two peaks of the backscatter intensity were measured: the first peak occurred during the waxing phase of the storm, the second was measured during the peak of flood discharge (Fig. 9d). At the Cap Creus canyon head, a first turbidity peak concomitant to the peak of the storm $(\mathrm{Hs}=4.7 \mathrm{~m}, 16$ April 02:00 h) was measured on 16 April 16:00 h with concentrations of 

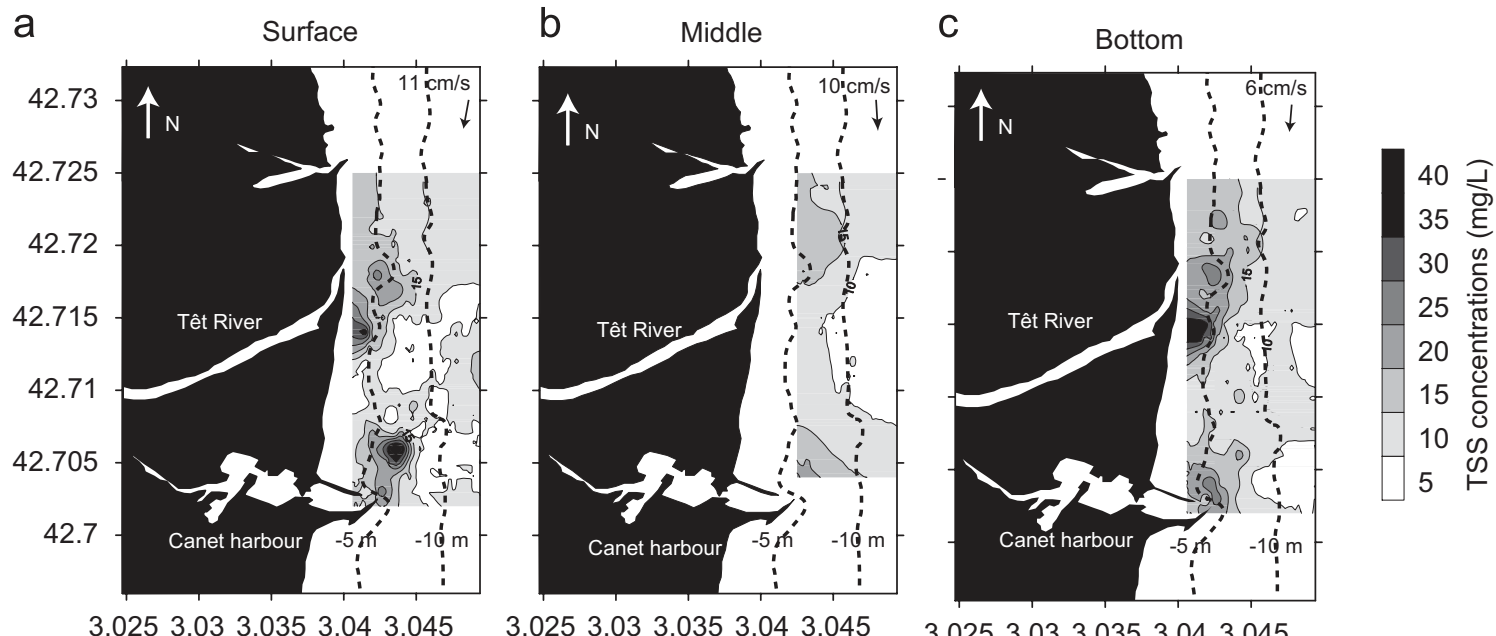



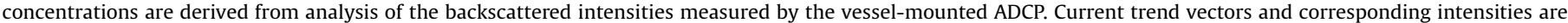
also indicated in the top-right corner of each figure.

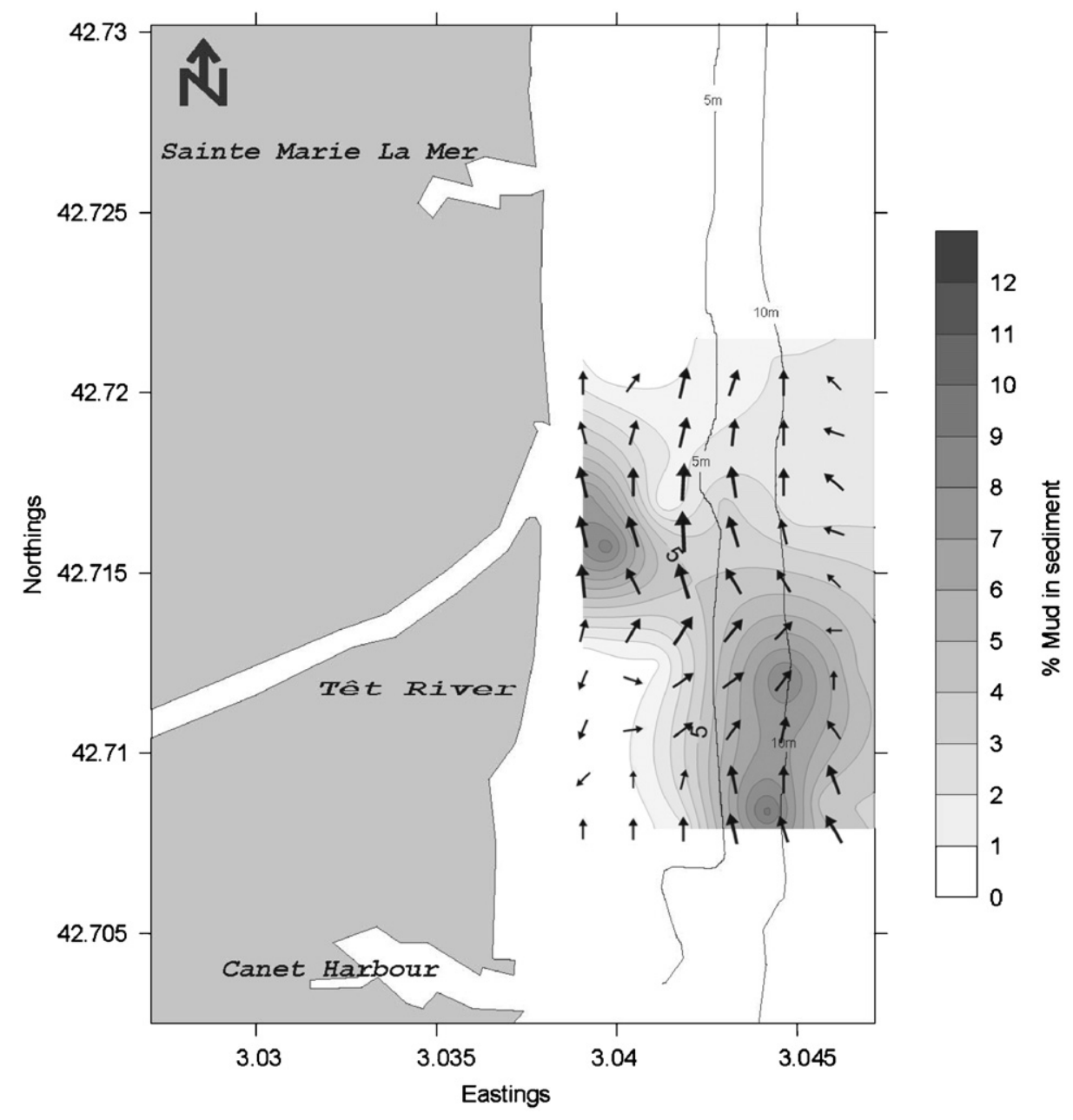


probable that trend is. Iso-lines of mud content ( $<63 \mu \mathrm{m}$ fraction) in surface sediment are also illustrated in the vicinity of the Têt River mouth.

$\sim 8 \mathrm{mg} \mathrm{L}^{-1}$ (Fig. 9e). A second turbidity peak was measured on 17 April 04:00 h, with concentrations of $\sim 20 \mathrm{mg} \mathrm{L}^{-1}, 14 \mathrm{~h}$ after the peak of the storm. A third turbidity peak was measured on 17
April 08:00 h with concentrations of $\sim 10 \mathrm{mg} \mathrm{L}^{-1}, 9 \mathrm{~h}$ after the peak flood of coastal rivers. No turbidity anomaly was measured in the Lacaze-Duthiers canyon further north. 
a

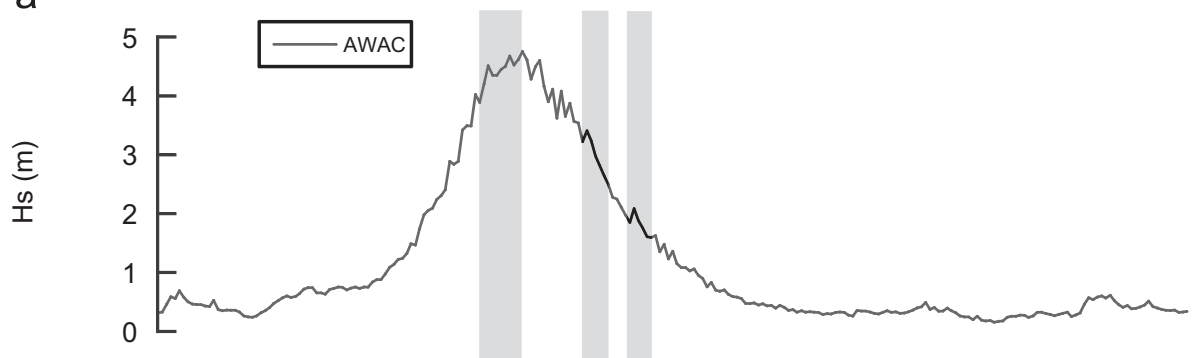

b
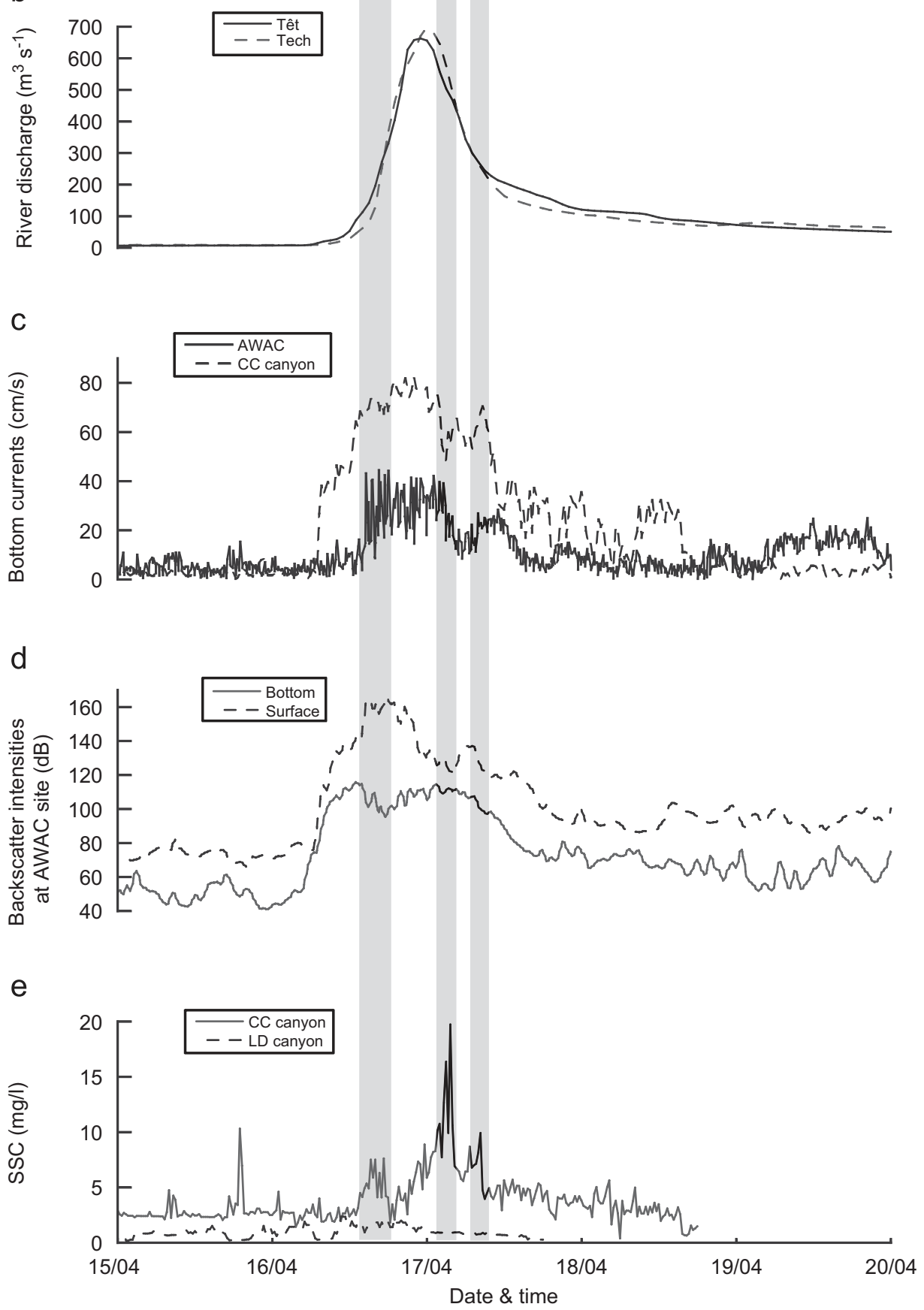

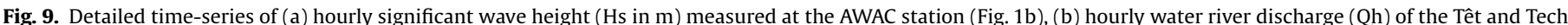

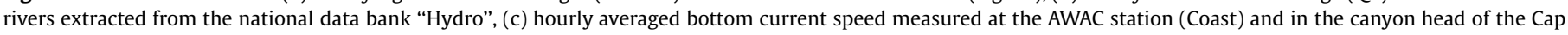

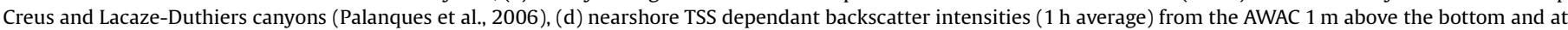


delimited with shaded areas. 


\section{Discussion}

\subsection{Sediment contribution of coastal rivers to the shelf}

\subsubsection{Total inputs to the shelf}

TSS discharge of the Têt River was estimated to be $\sim 33.9 \pm$ $0.6 \times 10^{3} \mathrm{t}$ of fine-grained sediment plus $\sim 11.4 \pm 0.2 \times 10^{3} \mathrm{t}$ of sand during the April 2004 flood event. This corresponds to more than half of the total mean annual suspended load of the Têt River $\left(\sim 61 \times 10^{3} \mathrm{t}\right)$ discharged in 3 days. The mean annual solid discharge of the rivers of the Gulf of Lions is $\sim 650 \times 10^{3} \mathrm{tyr}^{-1}$ compared to $10,200 \times 10^{3} \mathrm{tyr}^{-1}$ for the Rhône River, the largest river of the Gulf (Bourrin et al., 2006). However, during severe flood events, the suspended sediment contribution to the Gulf of Lions by small coastal rivers can have a major importance in comparison to the Rhône. For example, during the flood of April 2004, we estimated from existing rating curves (Bourrin et al., 2006) that the Têt and the adjacent Tech rivers together discharged $\sim 70 \times 10^{3} \mathrm{t}\left(+\sim 15 \times 10^{3}\right.$ t for the Agly River $)$ of sediment to the coastal zone, representing seven times the discharge of the Rhône $\left(\sim 10 \times 10^{3} \mathrm{t}\right)$ during the same period.

\subsubsection{Importance of the total sand transport}

The percentage of sand in the total suspended particulate matter, measured in surface water of the Têt River reached values of $\sim 20 \%$ during the flood. We estimated that about $25 \%$ of the total suspended load was composed of sand $\left(\sim 11.4 \pm 0.2 \times 10^{3} \mathrm{t}\right)$. The bedload transport of sand, estimated using SEDTRANS model ( $\mathrm{Li}$ and Amos, 2001), represented an additional load of $3.9 \pm$ $1.7 \times 10^{3} \mathrm{t}$.

Garcia-Estevez (2005) has shown that about $40 \%$ of TSS is retained by a dam, built between the alluvial plain and the mountainous part of the catchment, about $50 \mathrm{~km}$ upstream of the river mouth, to prevent flooding (Fig. 2). The flood of April 2004 occurred mainly in the lower part of the Têt River catchment, as indicated by the location of the cells of maximum rainfall (Fig. 2). In this part of the catchment, the dam has no effect on the river flow and TSS concentrations. Precipitation in the lower part of the catchment promoted erosion of sediments from easily erodible land located on the floodplain, and facilitated the transport of alluvial sediment in suspension towards the river mouth and the coastal zone. The precipitation pattern in the Têt River basin during this flood is typical of most of the flooding events occurring in this area. Other brief and violent flooding events have also occurred following intense precipitation higher in the Têt basin, as that was the case during the catastrophic event of 1940 (Pardé, 1941). The construction of the dam in the middle of the basin since 1978 limited the impact of the most recent extreme flood events.

Our results suggest that the Têt River delivers a higher or similar fraction of sand both in suspension and as bedload compared with other size-comparable rivers (Agly) and larger rivers (Rhône and Eel). By comparison, the Eel River, a larger mountainous river on the Californian margin, delivers $\sim 24 \%$ of its total solid discharge as sand in suspension (Crockett and Nittrouer, 2004). The Rhône River generally discharges 5\% of the total load of sand in suspension. This percentage can reach $\sim 15 \%$ during flood events (Antonelli, 2002).

Estimates based on global sediment budgets from worldwide rivers to the global ocean give a bedload value of about $10 \%$ of the total load (Milliman and Meade, 1983), which represents about $4.9 \times 10^{3} \mathrm{t}$ for the Têt River during this event (compared to $\sim 3.9 \pm 1.7 \times 10^{3} \mathrm{t}$ based on SEDTRANS model). For the Rhône River, estimates of bedload from IRS (2000) give values of $0.8-1.6 \times 10^{6} \mathrm{t} \mathrm{yr}^{-1}$, representing about $10 \%$ of the total suspended sediment discharge (2-17 $\times 10^{6} \mathrm{tyr}^{-1}$, from Antonelli, 2002; Pont et al., 2002). Serrat (1999) estimated that the bedload transport for a similar river located northward of the Têt River, the Agly River, is minimal ( $\sim 1 \%$ of the total load). One of the reasons for the higher transport of sand both in suspension and as bedload in the Têt River is because of the steep slope as its maximum headwater, which is located in the Pyrénées $(2100 \mathrm{~m})$. Another reason could be that the Têt River drains a large alluvial plain in the lower part of its catchment composed of easily erodible sediments.

\subsection{Sediment pathways in the nearshore}

\subsubsection{Coarse sediment transport}

No evidence of sandy deposits related to this flood was found close to the river mouth from the bathymetric survey (Fig. 10). Most of the sand introduced in the coastal zone probably bypassed the mouth through the river channel identified in the coastal area from the bathymetry survey (Fig. 10). This river channel is identified as a bypass area where the sand is transported but not deposited. Sand was caught by the northwards littoral drift during the peak storm, and nourished a modern sandy delta north of the mouth. The northerly direction of the littoral drift was already documented by Certain (2002) in the same area using successive bathymetric measurements. A relict delta was also observed from the bathymetric survey (Fig. 10) north of the river mouth, and was probably active during major floods of the last century (Delpont and Motti, 1994).

In our study, the Gao and Collins (1992) model can only give an indication of the sand transport direction which appears to be mainly northwards in the nearshore area of the Têt River (Manca, 2005). The resulting direction of the trend vectors depends strongly upon the density of sampling and the size of area sampled. This is problematic in a small deltaic environment, which is highly variable over short distances. For these reasons, results may be ambiguous. Nevertheless, the northerly transport of sands is supported by other evidences. Previous studies (Anguenot and Monaco, 1967; Certain, 2002; Delpont and Motti, 1994; Durand, 1999) refer to a northward littoral drift opposite to the general counterclockwise circulation in the southwestern Gulf of Lions (Fig. 1a). Anguenot and Monaco (1967) monitored a northward net sediment transport of radioactive sand in the nearshore of the Roussillon inner-shelf, associated with SE storms, and weaker southern net sediment transport associated with NW continental winds. Delpont and Motti (1994) showed the development of sand spits growing northwards at river mouths by studying satellite images at different periods of time.

Delpont and Motti (1994) also demonstrated that the configuration of the river mouth changed after flood events. In April 2004, the sand spit attached to the southern side of the Têt River mouth was removed from its position shown in marine charts. Indeed, the river mouth has two different configurations according to the river discharge regime. During low river discharge (few $\mathrm{m}^{3} \mathrm{~s}^{-1}$ ), a sand spit grows from south to north following the northward littoral drift. During high flooding conditions, river flow breaks through this sand spit. Delpont and Motti (1994) also observed local sand-trapping on the south side of Caneten-Roussillon and Sainte Marie harbours, suggesting a net northwards littoral drift. The bathymetric survey of the area conducted in April 2004 (Fig. 10) indicated that the orientation of sand bars does not appear to be a good indicator of the net sand transport direction because they are perturbed by the presence of the breakwater of the leisure harbour of Canet-en-Roussillon. But the artificial structure promoted the development of a sand spit growing from its southern tip toward the north. All the above features associated with the northward position of the nearshore 




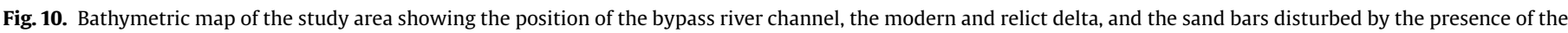
harbour breakwater.

submarine deltas (modern and relict) and the presence of a bypass channel oriented northwards, confirm the northward trend of the littoral drift of sand.

\subsubsection{Flood layer deposits}

Mud patches were observed in the nearshore area of the Têt River after the flood of April 2004. High mud content was measured in surface sediment directly in front of the river mouth and towards the south (Fig. 8) to a water depth of $10 \mathrm{~m}$. Sediment cores, taken after the flood event on 28 April 2004 showed a flood deposit at $20 \mathrm{~m}$ water depth; however, this was absent at $30 \mathrm{~m}$ water depth. The southwards current regime occurring during this flood (Fig. 3) restricted the offshore dispersion of fine-grained sediment.

TSS concentrations measured in surface river water were much too small to overcome the stratification between freshwater and saltwater, and produce bottom hyperpycnal flows (Mulder and Syvitski, 1995). Part of the fine sediments settled near the mouth; the remainder was advected with the surface hypopycnal plume southwards along the coast. Likewise, on other prodeltas associated with larger rivers (Rhône, Miralles et al., 2006; Po, Palinkas et al., 2005; Atchafalaya, Allison et al., 2000), no flood deposit was observed at depths greater than $40 \mathrm{~m}$ after flood events. The depth reached by these deposits depends on: (1) the strength of the flood in terms of liquid and solid discharges; (2) the wave climate of the receiving basin; and (3) the current regime during and following the peak discharge.

\subsection{River fine-grained sediment dispersal}

\subsubsection{Shelf transport}

The southward plume orientation revealed by grain-size analysis of the bed near the Têt River mouth is also shown in satellite imagery. The MERIS picture (Fig. 11), taken after the peak flood on 26 April 2004, shows the southward dispersion of river plumes along the Roussilllon coast. In this image, it is possible to distinguish the dispersion of several hypopycnal plumes from the Agly, Têt and Tech rivers on the shelf towards the southwestern canyons of the Gulf of Lions. River mouth plume events and their dispersal in the northwestern Mediterranean Sea have already been observed in large systems such as the Rhône and the Ebro (Arnau et al., 2004), but no observations have been investigated in the smaller systems. In this case, satellite imagery was possible only several days after the flood event, due to cloud cover during the passage of a low pressure system (Wheatcroft, 2000) and could reflect different conditions in the Têt inner-shelf.

Following Trump and Marmorino (2003), in which vesselmounted acoustical backscatter measurements were used to map river front structure, the southward orientation of the Têt surface plume was inferred from the water column acoustical backscatter data measured on 18 April 2004 (Fig. 7). Surface turbidity maxima were first observed at the entrance of the Canet-en-Roussillon harbour, corresponding to the draining of the harbour basin in response to the flood and the relaxation phase of the water mass after the storm induced surge in the harbour. Surface turbidity maxima were also observed south of the Têt River mouth, confirming the dispersal of the river plume towards the south, following the general circulation in the southwestern Gulf of Lions.

\subsubsection{Sediment export from the shelf}

Hydrodynamic modelling of the southwestern part of the Gulf of Lions on 16 April 2004 (Symphonie model; Ulses et al., 2008a; Fig. 12) predicted strong surface currents flowing along the coast towards the southern tip of the continental margin and the Cap Creus canyon head. Measured surface velocities at AWAC site reached a maximum of $0.80 \mathrm{~m} \mathrm{~s}^{-1}$ on 16 April 2004 during the peak of the storm and were oriented southward. The direction of measured and modelled currents agreed well, but the intensity of modelled currents $\left(\sim 0.40 \mathrm{~m} \mathrm{~s}^{-1}\right)$ was lower during this event. Nevertheless, fine particles entering the coastal area through hypopycnal plumes from the Roussillon coastal rivers (Agly, Têt, Tech) were thus rapidly advected southwardly by the general counter-clockwise circulation, thereby reaching the canyon head in less than a day. Near bottom measurements in the Cap Creus canyon head at the SW end of the Gulf indicate an increase of the current intensity and suspended sediment concentration shortly after the storm and river flood (Fig. 9). These increases were also related to the storm induced downwelling and the associated dense shelf water cascading occurring during this event (Palanques et al., 2006).

Exported sediment originated both from the river input of finegrained material, but also from the resuspension of shelf sediment and off-shelf advection by storm-induced downwelling. On one hand, our estimates of fine-grained supply by the three adjacent rivers (Agly, Têt and Tech) to the southwestern Gulf of Lions amounted to approximately $85 \times 10^{3} \mathrm{t}$. On the other hand, Ulses et al., 2008b) estimated from models that the export primarily 


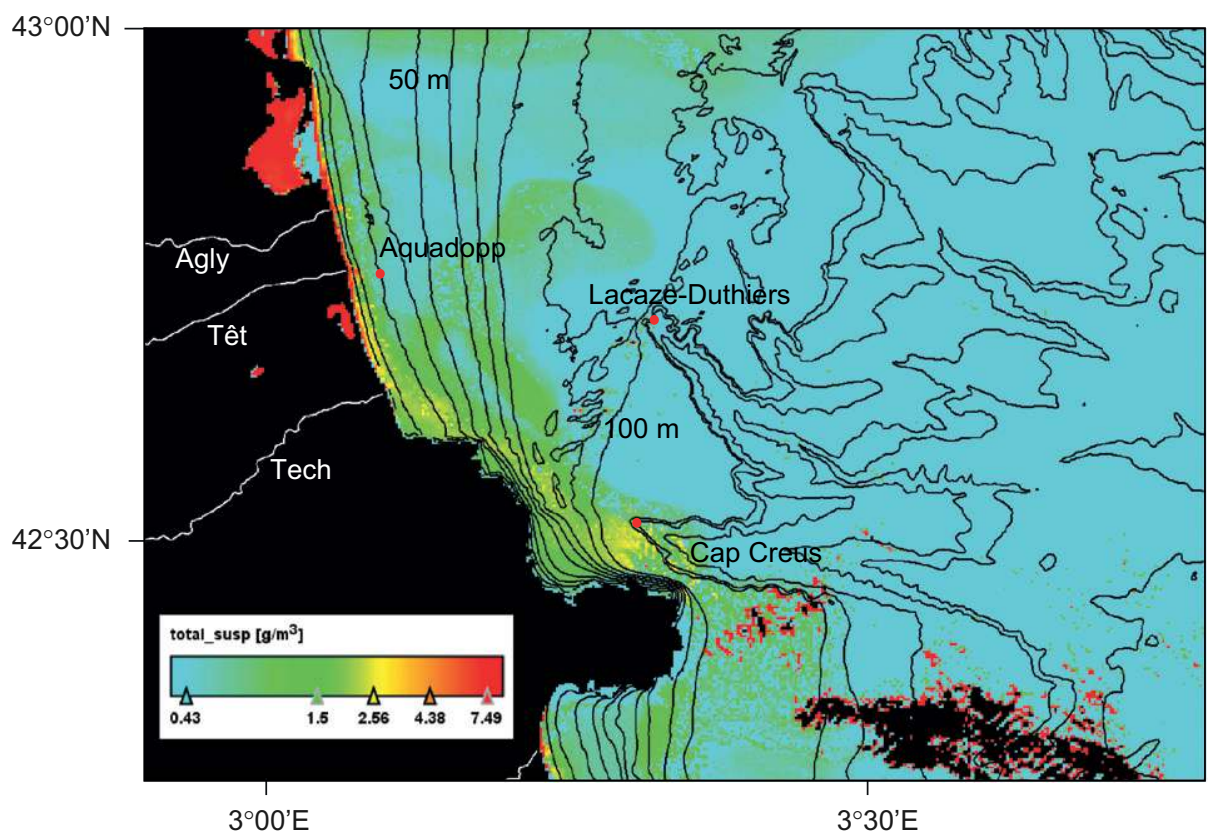




Hydrography and bathymetry are also shown, as well as the sampling stations (red circles).



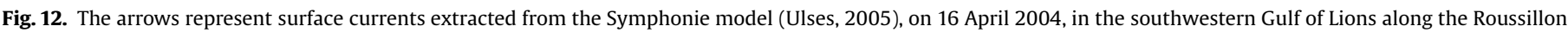


right. Measurement stations are indicated with red circles. 
took place through the Cap Creus canyon and the southernmost shelf, and amounted to $200 \times 10^{3} \mathrm{t}$, of which a large part originated from the shelf sediment resuspension. This could imply that river input contributed for about half to the off-shelf export of suspended sediment during that event, although it was being diluted by the large storm-induced resuspension that occurred on the shelf.

A schematic diagram of the sediment transport and deposition mechanisms of a typical flood event on a microtidal margin dominated by storms is presented in Fig. 13a. (1) A depression over the sea induced SE marine winds which promoted a typical storm event associated with a coastal storm surge. Waves induced seabed erosion in the coastal zone to about 20-30 m water depth. The storm also induced downwelling, which in the case of the southwestern Gulf of Lions, can reach the slope associated with dense shelf water cascading in the water mixing period (Palanques et al., 2006; Ulses et al., 2008a). In the nearshore (0-10 $\mathrm{m}$ water depth), sand was transported northwards as bedload in the breaker zone. (2) A few hours after the onset of the storm, precipitation in the catchment caused a flash-flood. Sand and mud were transported by rivers to the coastal area. The marine winds ceased, and northeasterly winds inverted the coastal current direction from a northerly to a southerly direction. Coastal currents and wave energy remained strong enough to


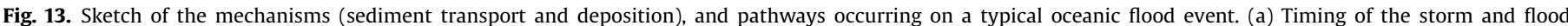



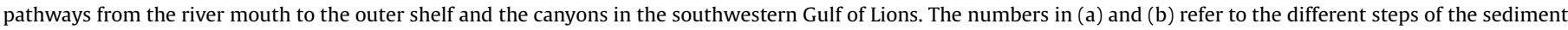
transport sequence along the Roussillon coast. Sedimentological features are also shown (redrawn from Aloïsi et al., 1973). 
maintain fine sediments in suspension, which bypassed the coastal area and were advected by currents directly southwards along the coast. (3) The storm passed, and fine-grained hypopycnal plumes flowed southwards along the coast, reaching the Cap Creus area. (4) River discharge remained high while alongshore currents decreased; mud was deposited in the inner-shelf south of the river mouth. Thus, according to our observations (Fig. 13b), coarse-grained sediment transport was restricted to the nearshore. Part of the fine-grained sediment settled close to river mouths on prodeltas; part was advected directly southwards to the Cap Creus canyon head and along the coast. Prodeltas constitute early muddy deposits at river mouths (Roussiez et al., 2005) and feed the mid-shelf mud belt in a multi-step pathway following storm events (Guillén et al., 2006). Flood events with relatively short return intervals on small mountainous rivers can thus play a significant role in the supply of coarse sediment to the inner-shelf, and contribute to the dispersal and export of finegrained sediment across the shelf and, through the canyons, to the continental slope, depending on local geography and shelf circulation. The fine-grained sediment transport across the shelf thus occurred directly towards the continental slope during floods through hypopycnal plumes, and in multi-step pathways from the erosion of prodeltas and the mid-shelf mud belt during storm events.

\section{Conclusions}

The most important findings of this work are as follows.

(1) A flash-flood event was observed in April 2004 on the Têt River. About half of the annual load was discharged in a few days during this flood. As maximum precipitation cells were localised in the lower part of the basin, the dam in the middle of the Têt River catchment did not prevent sand transport to the coastal zone during this event. The heavy rain near the coastal plain promoted erosion of easily erodible lands.

(2) Large amounts of sand and mud in suspension were thus carried by the river to the coastal zone. River sand was trapped in the nearshore and was subsequently moved alongshore to the north as bedload, as indicated by a small delta and the direction of sand spit growth. At the same time, river fines were separated at the mouth: a part settled towards the south and the finest fraction was advected towards the Cap Creus canyon through a hypopycnal plume, where it exited the shelf within a few hours after the flood peak.

(3) Next to major flood events of large-size rivers, e.g. the Rhône, small mountainous rivers can play a significant role in the supply of sediment to continental shelves and, due the local geography and circulation in the NW Mediterranean Sea, can contribute significantly to the export of sediment from the continental margin.

\section{Acknowledgements}

The authors would like to thank the "Communaute d'Agglomération Perpignan Méditerranée" for providing wind, current and wave data, initially measured during the construction's study of a waste water pipe in the coastal area of the Têt River. This work was supported by the European project Eurostrataform (contract number EVK3-CT-2002-00079). We would also thank two anonymous reviewers who gave useful comments and contributed to upgrade an earlier version of this manuscript.

\section{References}

Allison, M.A., Kineke, G.C., Gordon, E.S., Goñi, M.A., 2000. Development and reworking of a seasonal flood deposit on the inner continental shelf off the Atchafalaya River. Continental Shelf Research 20 (16), 2267-2294.

Aloïsi, J.C., Got, H., Monaco, A., 1973. Carte géologique du précontinent languedocien au 1/250000ième. International Institute for Aerial Survey and Earth Sciences (I.T.C.), Netherlands.

Anguenot, F., Monaco, A., 1967. Etude de transits sédimentaires, sur le littoral du Roussillon, par la méthode des traceurs radioactifs. Cahiers Océanographiques 19 (7), 579-589.

Antonelli, C., 2002. Flux sédimentaires et morphogenèse récente dans le chenal du Rhône aval. Ph.D. Thesis, Université Aix-Marseille I, 279pp.

Arnau, P., Liquete, C. Canals, M., 2004. River mouth plume events and their dispersal in the Northwestern Mediterranean Sea. Oceanography 17 (3), 22-31.

Bourrin, F., Durrieu de Madron, X., Ludwig, W., 2006. Contribution of the study of coastal rivers and associated prodeltas to sediment supply in North-western Mediterranean Sea (Gulf of Lions). Life and Environment 56 (4), 1-8.

Buscail, R., Pocklington, R., Daumas, R., Guidi, L., 1990. Fluxes and budget of organic matter in the benthic boundary layer over the northwestern Mediterranean margin. Continental Shelf Research 10 (9-11), 1089-1122.

Buscail, R., Pocklington, R., Germain, C., 1995. Seasonal variability of the organic matter in a sedimentary coastal environment: sources, degradation and accumulation (continental shelf of the Gulf of Lions-northwestern Mediterranean Sea). Continental Shelf Research 15 (7), 843-869.

Certain, R., 2002. Morphodynamique d'une côte sableuse microtidale à barres: le Golfe du Lion (Languedoc-Roussillon). Ph.D. Thesis, Université Perpignan, 209pp.

Courp, T., Monaco, A., 1990. Sediment dispersal and accumulation on the continental margin of the Gulf of Lions: sedimentary budget. Continental Shelf Research 9-11, 1063-1088.

Creed, E.L., Pence, A.M., Rankin, K.L., 2001. Inter-comparison of turbidity and sediment concentration measurements from an ADP, an OBS-3, and a LISST, OCEANS. MTS/IEEE Conference and Exhibition, vol. 3, 2001, pp. 1750-1754

Crockett, J.S., Nittrouer, C.A., 2004. The sandy inner shelf as a repository for muddy sediment: an example from Northern California. Continental Shelf Research 24 (1), 55-73.

Delpont, G., Motti, E., 1994. Monitoring by remote sensing of the geomorphological evolution of a part of the Roussillon coastal layout (France). OCEANIS 94 OSATES, pp. 44-47.

Durand, P., 1999. L'évolution des plages de l'ouest du Golfe du Lion au XXème siècle. Ph.D. Thesis, Université Lumière Lyon 2, 461 pp.

Estournel, C., Durrieu de Madron, X., Marsaleix, P., Auclair, F., Julliand, C., Vehil, R., 2003. Observation and modeling of the winter coastal oceanic circulation in the Gulf of Lion under wind conditions influenced by the continental orography (FETCH experiment). Journal of Geophysical Research 108 (C3), 8059.

European Space Agency. MERIS product handbook, from <http://envisat.esa.int/ envisat/dataproducts/>, 2002.

Ferré, B., Guizien, K., Durrieu de Madron, X., Palanques, A., Guillén, J., Grémare, A., 2005. Fine-grained sediment dynamics during a strong storm event in the inner-shelf of the Gulf of Lion (NW Mediterranean). Continental Shelf Research 25, 2410-2427.

Folk, R.L., Ward, W.C., 1957. Brazos River bar: a study in the significance of grainsize parameters. Journal of Sediment Petrolology 27 (1), 3-26.

Gao, S., 1996. A FORTRAN program for grain-size trend analysis to define net sediment transport pathways. Computers and Geosciences 22 (4), 449-452.

Gao, S., Collins, M., 1992. Net sediment transport patterns inferred from grain-size trends, based upon definition of "transport vectors". Sedimentary Geology 81 (1-2), 47-60.

Garcia-Estevez, J., 2005. Géochimie d'un fleuve côtier méditerranéen: la Têt en Roussillon. Origines et transferts de matières dissoutes et particulaires de la source jusqu'à la mer. Ph.D. Thesis, Université Perpignan, 263pp.

Garcia-Esteves, J., Ludwig, W., Kerherve, P., Probst, J.-L., Lespinas, F., 2007. Predicting the impact of land use on the major element and nutrient fluxes in coastal Mediterranean rivers: the case of the Têt River (Southern France). Applied Geochemistry 22 (1), 230-248.

Gaume, E., Livet, M., Desbordes, M., Villeneuve, J.-P., 2004. Hydrological analysis of the river Aude, France, flash flood on 12 and 13 November 1999. Journal of Hydrology 286 (1-4), 135-154.

Guidi-Guilvard, L.D., Buscail, R., 1995. Seasonal survey of metazoan meiofauna and surface sediment organics in a non-tidal turbulent sublittoral prodelta (northwestern Mediterranean). Continental Shelf Research 15 (6), 633-653.

Guillén, J., Jiménez, J.A., Palanques, A., Garcia, V., Puig, P., Sanchez-Arcilla, A., 2002. Sediment resuspension across a microtidal, low-energy inner shelf. Continental Shelf Research 22, 305-325.

Guillén, J., Bourrin, F., Palanques, A., Durrieu de Madron, X., Puig, P., Buscail, R., 2006. Sediment dynamics during wet and dry storm events on the Têt inner shelf (SW Gulf of Lions). Marine Geology 234 (1-4), 129-142.

Hill, P.S., Milligan, T.G., Geyer, W.R., 2000. Controls on effective settling velocity of suspended sediment in the Eel River flood plume. Continental Shelf Research 20 (16), 2095-2111.

IRS, 2000. Etude globale pour une stratégie de réduction des risques dus aux crues du Rhône. Etude du transport solide, 1ère étape, rapport de synthèse. Institut Inter-Départementale des Bassins Rhône-Saône, Valence, France. 
Land, J.M., Bray, R.N., 2000. Acoustic measurement of suspended solids for monitoring of dredging and dredged material disposal. Journal of Dredging Engineering 2 (3), 1-17.

Li, M.Z., Amos, C.L., 1995. SEDTRANS92: a sediment transport model for continental shelves. Computers and Geosciences 21 (4), 533-554.

Li, M.Z., Amos, C.L., 2001. SEDTRANS96: the upgraded and better calibrated sediment-transport model for continental shelves. Computers and Geosciences 27, 619-645.

Liu, J.T., Lin, H.-L., 2004. Sediment dynamics in a submarine canyon: a case of river-sea interaction. Marine Geology 207 (1-4), 55-81.

Ludwig, W., Serrat, P., Cesmat, L., Garcia-Esteves, J., 2004. Evaluating the impact of the recent temperature increase on the hydrology of the Têt River (Southern France). Journal of Hydrology 289 (1-4), 204-221.

Manca, E., 2005. La dinamica sedimentaria nell'ambiente deltizio del flume Têt (Francia Meridionale). Master Thesis, University of Genova.

Milliman, J.D., Meade, R.H., 1983. World-wide delivery of sediment to the oceans. Journal of Geology 91 (1), 1-21.

Milliman, J.D., Syvitski, J.P.M., 1992. Geomorphic/tectonic control of sediment discharge to the ocean: the importance of small mountainous rivers. Journal of Geology 100 (5), 525-544.

Millot, C., 1976. Specific features of the sea-shore circulation near Cap Leucate. Mémoires, Société Royale des Sciences de Liège, 6e série (tome X), pp. 227-245.

Miralles, J., Arnaud, M., Radakovitch, O., Marion, C., Cagnat, X., 2006. Radionuclide deposition in the Rhône River Prodelta (NW Mediterranean Sea) in response to the December 2003 extreme flood. Marine Geology 234 (1-4), 179-189.

Mulder, T., Syvitski, J.P.M., 1995. Turbidity currents generated at river mouths during exceptional discharges to the world oceans. Journal of Geology 103 , 285-299.

Palanques, A., Puig, P., Guillen, J., Jimenez, J., Gracia, V., Sanchez-Arcilla, A., Madsen, O., 2002 Near-bottom suspended sediment fluxes on the microtidal lowenergy Ebro continental shelf (NW Mediterranean). Continental Shelf Research 22 (2), 285-303.

Palanques, A., Durrieu de Madron, X., Puig, P., Fabres, J., Guillen, J., Calafat, A. Canals, M., Heussner, S., Bonnin, J., 2006. Suspended sediment fluxes and transport processes in the Gulf of Lions submarine canyons. The role of storms and dense water cascading. Marine Geology 234 (1-4), 43-61.

Palinkas, C.M., Nittrouer, C.A., Wheatcroft, R.A., Langone, L., 2005. The use of 7Be to identify event and seasonal sedimentation near the Po River delta, Adriatic Sea. Marine Geology 222-223, 95-112.

Pardé, M., 1941. La formidable crue d'octobre 1940 dans les Pyrénées-Orientales. Revue géographique des Pyrénées et du Sud-Ouest, pp. 237-279.

Pont, D., Simonnet, J.-P., Walter, A.V., 2002. Medium-term changes in suspended sediment delivery to the ocean: consequences of catchment heterogeneity and river management (Rhone River, France). Estuarine Coastal and Shelf Sciences 54 (1), 1-18.

Puig, P., Palanques, A., Guillén, J., 2001. Near-bottom suspended sediment variability caused by storms and near-inertial internal waves on the Ebro mid continental shelf (NW Mediterranean). Marine Geology 178 (1-4), 81-93.

Rivière, A., 1977. Méthodes Granulométriques; Techniques et Interprétations. Masson, Paris, 170pp.

Rouse, H., 1937. Modern conceptions of the mechanics of fluid turbulence. Transactions of the American Society of Civil Engineering 102, 463-554.

Roussiez, V., Aloisi, J.-C., Monaco, A., Ludwig, W., 2005. Early muddy deposits along the Gulf of Lions shoreline: a key for a better understanding of land-to-sea transfer of sediments and associated pollutant fluxes. Marine Geology 222/ 223, 345-358.

Sandwell, D.T., 1987. Biharmonic spline interpolation of GEOS-3 and Seasat altimeter data. Geophysical Research Letters 14 (2), 139-142.

Serrat, P., 1999. Dynamique sédimentaire actuelle d'un système fluvial méditerranéen: l'Agly (France). Comptes Rendus de l'Académie des Sciences Paris Série D 329, 189-196.

Serrat, P., Ludwig, W., Navarro, B., Blazi, J.-L., 2001. Variabilité spatio-temporelle des flux de matières en suspension d'un fleuve côtier méditerranéen: la Têt (France). Comptes Rendus de l'Académie des Sciences Paris Série D 333, 389-397.

Standard Methods for the Examination of Water and Wastewater, 17th ed., 1989.

Trump, C.L., Marmorino, G.O., 2003. Mapping small-scale along-front structure using ADCP acoustic backscatter range-bin data. Estuaries 26 (4), 878-884.

Ulses, C., 2005. Dynamique océanique et transport de la matière particulaire dans le Golfe du Lion: crue, tempête et période hivernale. Ph.D. Thesis, Université Paul Sabatier, Toulouse, 247pp.

Ulses, C., Estournel, C., Bonnin, J., Durrieu de Madron, X., Marsaleix, P., 2008a Impact of storms and dense water cascading on shelf-slope exchanges in the Gulf of Lion (NW Mediterranean). Journal of Geophysical Research 113, C02010.

Ulses, C., Estournel, C., Durrieu de Madron, X., Palanques, A, 2008b. Suspended Sediment Transport in the Gulf of Lion (NW Mediterranean): impact of extreme storms and floods. Continental Shelf Research, this issue, doi:10.1016/ j.csr.2008.01.015

Urick, R.J., 1975. Principles of Underwater Sound. McGraw-Hill, New York, 384pp.

Wheatcroft, R.A., 2000. Oceanic flood sedimentation: a new perspective. Continental Shelf Research 20 (16), 2059-2066.

Wheatcroft, R.A., Borgeld, J.C., 2000. Oceanic flood deposits on the northern California shelf: large-scale distribution and small-scale physical properties. Continental Shelf Research 20 (16), 2163-2190.

Winston, W.E., Criss, R.E., 2002. Geochemical variations during flash flooding Meramec River basin, May 2000. Journal of Hydrology 265 (1-4), 149-163.

Yalin, M.S., 1963. An expression for bedload transportation. Journal of the Hydraulics Division ASCE 89 (HY3), 221-250. 